\title{
To Act or Not to Act: Are Natural Landscapes a Key Force in the Resilience of Historic Urban Landscapes?
}

\author{
Wei Gao ${ }^{1}\left(\mathbb{D}\right.$, Gengyu Chen ${ }^{1,2}$, Fanying Jiang ${ }^{1}\left(\mathbb{D}\right.$, Jiake Shen ${ }^{3}$ and Yuncai Wang ${ }^{3, *(\mathbb{C}}$ \\ 1 College of Forestry and Landscape Architecture, South China Agricultural University, Guangzhou 510642, \\ China; gaowei@scau.edu.cn (W.G.); dennis_chengy@163.com (G.C.); riverify@hotmail.com (F.J.) \\ 2 Pubang Landscape Architecture Co., Ltd., Guangzhou 510699, China \\ 3 College of Architecture and Urban Planning, Tongji University, Shanghai 200092, China; \\ jiakeshen1991@tongji.edu.cn \\ * Correspondence: wyc1967@tongji.edu.cn
}

check for updates

Citation: Gao, W.; Chen, G.; Jiang, F.; Shen, J.; Wang, Y. To Act or Not to Act: Are Natural Landscapes a Key Force in the Resilience of Historic Urban Landscapes? Sustainability 2021, 13, 10356. https://doi.org/ $10.3390 /$ su131810356

Academic Editor: Ashish Sharma

Received: 10 July 2021

Accepted: 15 September 2021

Published: 16 September 2021

Publisher's Note: MDPI stays neutral with regard to jurisdictional claims in published maps and institutional affiliations.

Copyright: (C) 2021 by the authors. Licensee MDPI, Basel, Switzerland. This article is an open access article distributed under the terms and conditions of the Creative Commons Attribution (CC BY) license (https:/ / creativecommons.org/licenses/by/ $4.0 /)$.

\begin{abstract}
Ignoring the function of natural landscapes in the rapid development of urbanization, and especially in the conservation of historic urban landscapes, is still obvious today, and this has caused a large decrease in natural space, loss of habitats, and an increase in disasters. The resilience of a whole city and parts of it, such as historic urban areas where the historical process of man and nature have been recorded, as well as the interaction between nature, economy, and culture, is not strong enough to maintain the stability of urban ecosystems. It is misleading to think that the resilience can be built in a historic urban area without a natural landscape. We question whether this is true. Using a semantic differential analysis method from a historical perspective, this paper aims to answer this question through research on the correlation between resilience and man and nature through a case study of Yudai Trench historic urban landscape in Guangzhou, a historic urban area with 1000 years of history. A total of 212 pieces of evidence were extracted from 59 historical sources. The results showed that the cultural and economic conditions were in the same step and cycles as nature, which were influenced strongly by climate change, and that the natural landscape has a correlation on and is a dominant force in the resilience of historic urban landscapes.
\end{abstract}

Keywords: urban resilience; historic urban landscape; climate change; semantic differential analysis; Yudai Trench historic urban landscape

\section{Introduction}

Nowadays, in the face of natural, economic, and cultural urban development problems such as biodiversity loss, heat island effect, cultural fragmentation, and frequent occurrence of diseases [1-7], the 2030 Agenda for Sustainable Development of the United Nations has proposed that urban sustainable development should be "inclusive, safe, resilient and sustainable" [8]. How to improve the ecological resilience of cities, enhance the ability to cope with various external and internal impacts of cities, and promote sustainable urban development are major challenges facing cities around the world [9-11].

Urban landscapes are designed to stabilize urban resilience by addressing a wide range of environmental problems in cities and preventing sudden impacts [12-14]. In the context of climate change, if the complexity of urban landscapes is not accurately understood, irreversible damage to urban resilience will occur $[15,16]$.

Historic urban landscapes are the product of historical overlapping interactions among natural systems, economic systems, and cultural systems and are an important carrier of urban resilience [17]. Throughout history, there have been many famous historic urban landscape cases that have provided important support for the urban resilience of cities, such as Central Park in New York City, the irrigation system of Dujiang Weir in Sichuan, and the Tuancheng drainage system in Beijing [18-21]. At present, the related research on historic urban landscapes can be divided into two categories: research on historical 
value and research on conservation and renewal [22]. Firstly, the research carried out from the perspective of historical value focuses on textual research and sorting out the cultural value and change process of historic urban landscapes and summarizes the spatial pattern characteristics of these landscapes [23,24]. Secondly, the study on the conservation and renewal of historic urban landscapes focuses on discussing the optimal conservation and renewal strategies of the existing historical landscape for the future $[25,26]$.

In the research on historic urban landscapes created by human activities, the content is often based on the study of architecture and archaeology in spatial forms $[22,27,28]$. The literature also focuses on the evaluation, conservation, and renewal of the cultural value of existing historic urban landscapes and pays less attention to the role of natural landscapes [22]. From a historic urban landscape perspective, the research on the correlation of human ecosystems and the change mechanism of urban resilience from the perspective of coping with the impact of climate change needs to be enriched to provide convincing case [22,29-31].

In this paper, the Yudai Trench historic urban landscape in Guangzhou was selected as the research object, with the aim of exploring the key forces of resilience of a historic urban landscape and an analysis of the change mechanism of resilience. This paper proposes four hypotheses that need to be tested: (1) the Yudai Trench historic urban landscape has resilience to climate change; (2) the natural, economic, and cultural systems have correlations; (3) the natural system has dominance and priority in the resilience change; (4) there is a limit to the resilience of natural landscapes.

Through semantic differential analysis, semantic intensities of 212 historical records related to natural, economic, and cultural systems of the Yudai Trench historic urban landscape from 1011 to 2000 were extracted, and the change curves of three systems and climate change were constructed based on the width of Yudai Trench. The correlations between natural, economic, and cultural systems under the impact of climate change were contrastively analyzed, and the key force of resilience and the change mechanism of resilience of the Yudai Trench historic urban landscape was explored in depth.

\section{Materials and Methods}

\subsection{Study Area}

Yudai Trench is a haven dug during the Northern Song Dynasty (1011) in order to protect Guangzhou from typhoon disasters caused by unstable air flow in the tropical monsoon area [32]. It is located under the southern city wall of Guangzhou and historically had the functions of both city defense and urban water transport. In addition, Wenxi River, West Lake, and Nan Trench were its water sources in the north.

Since the Song Dynasty, commercial and cultural centers such as Gaodi Street, Haopan Street, and Nanyuan Garden emerged because of the convenient east-west water transportation and the functions of windproofing and disaster prevention. Among them, Gaodi Street and Haopan Street were well-known commercial streets for salt transportation, Canton-style furniture, and musical instrument manufacture and sale, and Nanyuan Garden was the origin of Lingnan poetics. Nowadays, Yudai Trench has turned into an ordinary street in the old city of Guangzhou, and the prosperity of the Yudai Trench historic urban landscape is no longer visible $[32,33]$.

The selection of the Yudai Trench coastal historic urban landscape (Figure 1) as the research subject is based on its thousand-year history (1011-2000) and its cardinal position in urban resilience. It provides a record of the city's urban development over the last 1000 years. Therefore, it also provides a constant and complete sample for the study of the relationships between the natural, economic, and cultural systems of a historic urban landscape in a first-grade city's development. 


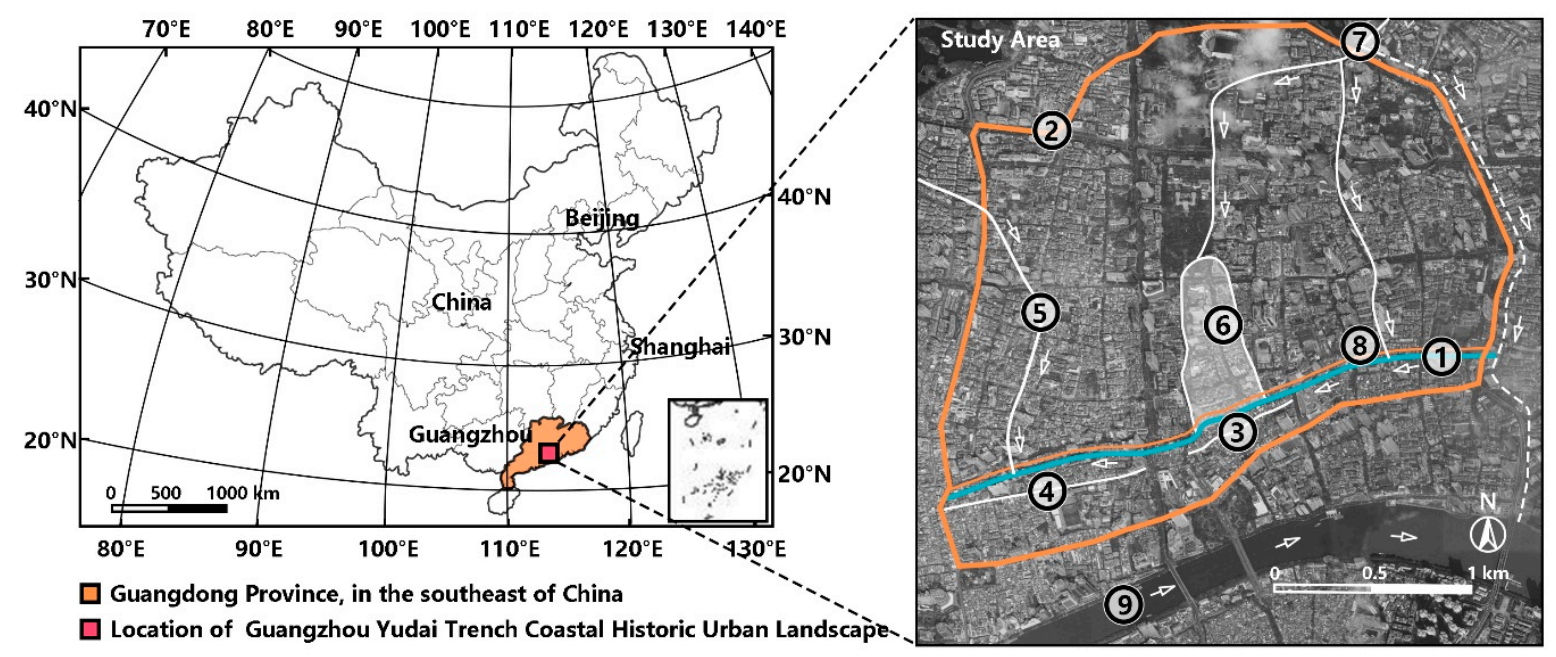

Figure 1. Location and map of the Yudai Trench coastal historic urban landscape. (Place names and descriptions can be found in Appendix A).

\subsection{Methodology}

\subsubsection{Research Framework}

This study mainly includes the following two aspects (Figure 2).

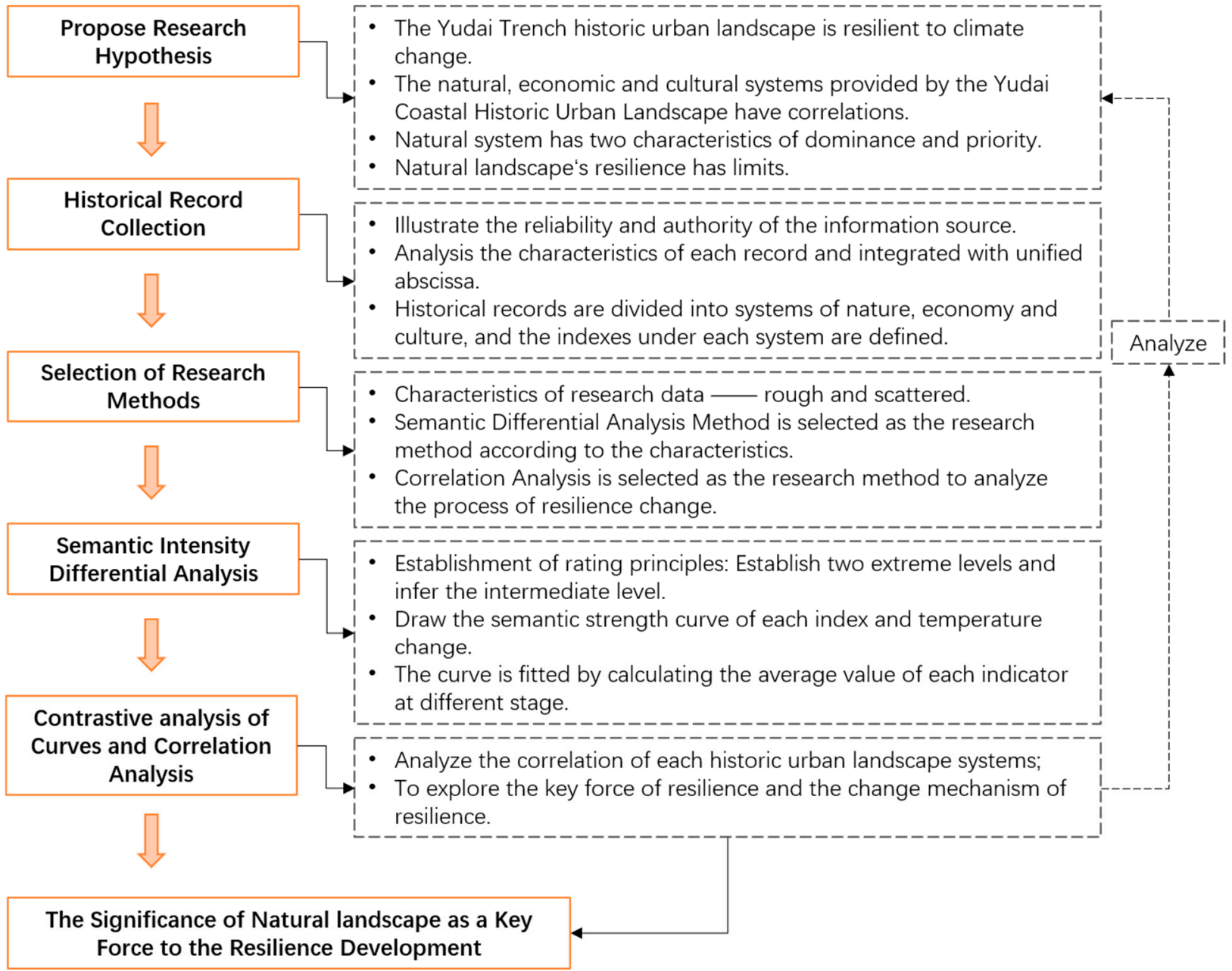

Figure 2. Framework of research. 
First, semantic differential analysis was used to analyze the hypothesis. Based on the historical records of the Yudai Trench historic urban landscape, semantic intensity analysis, data integration, and semantic intensity change curve construction were carried out. The periodicity, interaction, and correlations between natural, economic, and cultural systems were analyzed in the macroscopic context of climate change, and the natural landscape is the key force of the dominant system and the resilience of historic urban landscapes.

Secondly, correlation analysis was used to further analyze the resilience change process of the Yudai Trench historic urban landscape and to uncover the reasons for its disappearance. Then, the mechanism of natural landscapes as a key force of resilience was explored, and the contemporary value of historic urban landscapes for urban resilience and sustainable development is summarized.

\subsubsection{Characteristic Index of the Yudai Trench Historic Urban Landscape}

The historical records of the Yudai Trench coastal historic urban landscape are not constant over time, but rather have a scattered distribution. Therefore, there are numerous record gaps when we plot the semantic intensity change curves of various historical records with the time axis as the abscissa. However, taking the width of the Yudai Trench as the abscissa of the change curve of the historical records, the scattered historical records can be summarized into eight time periods, including the periods of the Song Dynasty to the Yuan Dynasty (1011-1271), the Yuan Dynasty to the Ming Dynasty (1271-1380), the Ming Dynasty (1380-1564), the Ming Dynasty (1564-1644), the Ming Dynasty to the Qing Dynasty (1644-1738), the Qing Dynasty to the Republic of China (1738-1918), the Republic of China (1918-1949), and the People's Republic of China (1949-the present day). In this way, the scattered records can be effectively integrated to form complete records with a time span of nearly 1000 years.

In this paper, we further categorize the integrated records according to natural, economic, and cultural indexes on the basis of the records' integration (Table 1). The ability of the natural system to withstand the impact of climatic disasters mainly depends on the water-holding capacity of the internal water landscape [34]. Water landscapes are the catchment area of the city. The greater the water-holding capacity, the stronger the ability to resist typhoons and floods $[35,36]$. Therefore, the data related to water-holding capacity of Yudai Trench, West Lake, and Nanhao Trench were found from historical records, and the width, area, and volume of these were determined as indexes.

The state of the economic system can be reflected in the scale of commerce and import and export trade within the historic urban landscape [37]. The commercial scale selects the core industry and the number of commercial shops in the historic urban landscape as the indexes [22,37]. In terms of import and export trade, the import of musical instruments and furniture materials and the export of finished products occupy the vast majority of the imports and exports of the Yudai Trench historic urban landscape, and its production and sales are of representative significance [32,37].

The state of cultural systems depends on the active degree of literati activities and the level of cultural technology innovation [37]. As traditional Chinese art creations, poetry, painting and landscape construction possess the same origin, the literati activities of Lingnan poetry are combined with the construction of the South Garden [38]. The construction scale of the South Garden is an important index reflecting the activity of the literati. In addition, the Yudai Trench historic urban landscape is a core area of the integration and collision of Chinese and Western cultures [39]. The integration of musical instruments and Cantonese-style furniture reflects the inclusive and innovative ability of culture $[37,40]$. 
Table 1. Index of the characteristics of the Yudai Trench historic urban landscape.

\begin{tabular}{|c|c|c|}
\hline Index Attribute & Index & Index Description \\
\hline \multirow{3}{*}{ Natural System Index } & The width of the Yudai Trench & $\begin{array}{l}\text { The width reflects the city's ability to cope with } \\
\text { typhoons and floods. }\end{array}$ \\
\hline & The area of the West Lake & $\begin{array}{l}\text { The area is a measure index of the water used for } \\
\text { citizens' living and working requirements and disaster } \\
\text { prevention in Guangzhou. }\end{array}$ \\
\hline & The volume of the Nanhao Trench & $\begin{array}{l}\text { The volume is an index of Guangzhou's ability to store } \\
\text { water, replenish water, and deal with disasters such as } \\
\text { floods and droughts. }\end{array}$ \\
\hline \multirow{5}{*}{ Economic System Index } & The scale of Yudai Trench commerce & $\begin{array}{l}\text { The index reflects the commercial scale of the core } \\
\text { business district of Guangzhou. }\end{array}$ \\
\hline & The number of shops in Gaodi Street & $\begin{array}{l}\text { It reflects the economic prosperity of the Yudai Trench } \\
\text { historic urban landscape. }\end{array}$ \\
\hline & Salt storage & $\begin{array}{l}\text { It reflects the economic prosperity of the Yudai Trench } \\
\text { historic urban landscape. }\end{array}$ \\
\hline & Quantity of musical instruments produced and sold & $\begin{array}{l}\text { It is the index of export trade of the Yudai Trench } \\
\text { historic urban landscape }\end{array}$ \\
\hline & Quantity of Cantonese-style furniture produced and sold & $\begin{array}{l}\text { It is the index of wood imports and furniture exports of } \\
\text { the Yudai Trench historic urban landscape. }\end{array}$ \\
\hline \multirow{3}{*}{ Cultural System Index } & The construction scale of Nanyuan Garden & $\begin{array}{l}\text { It is the index that can reflect the active degree of } \\
\text { literati activities around the Yudai Trench historic } \\
\text { urban landscape. }\end{array}$ \\
\hline & The innovation level of musical instruments & $\begin{array}{l}\text { It reflects the index of the craft level and the aesthetic } \\
\text { level of citizens. }\end{array}$ \\
\hline & The innovation level of Cantonese-style furniture & $\begin{array}{l}\text { It is the index of the culture's ability to absorb and } \\
\text { innovate foreign aesthetic culture and advanced } \\
\text { technology. }\end{array}$ \\
\hline
\end{tabular}

\subsubsection{Semantic Differential Analysis and Semantic Intensity Rating}

The semantic differential analysis method (referred as SD hereafter) was first proposed by Osgood to examine the emotional meaning of words [41]. Since it can quantize emotional vocabulary, it is widely applied in linguistics and psychology [42,43]. SD works according to the evaluation score of the emotional vocabulary scale, and both extremities of the scale use comparative adjectives (such as good and bad, big and small) [41]. In recent years, SD has been increasingly applied in the study of landscape evaluation, such as in rural landscape evaluation based on ancient Chinese poems [44], landscape aesthetic value evaluation combined with photographic images [45-47], and in the optimization of soundscape design practices [48]. Li et al. converted qualitative descriptions from literature sources into quantitative data to propose optimization recommendations for rural landscapes [44]. In this study, we drew on these previous achievements to convert the emotional vocabulary records that express the natural, economic, and cultural systems of the Yudai Trench into quantifiable indexes.

However, there are many corrupted records in the historical records. The lowest level and the highest level of emotional words of each index should be prioritized, and the middle level of emotional words can be inferred through the two superlatives. By screening the treatment of the collected emotional words, such as through the optimal selection of similar words, the elimination of ineffective words, and other treatments, the lowest level and the highest level of emotional words for each index were finally determined (more details can be found in Appendix B).

In order to better explain the process of SD of the various indexes, we took "the area of the West Lake" as an example for explanation (Table 2). West Lake was a freshwater wetland in the ancient city of Guangzhou. It provided a range of critically important ecosystem services including fresh water for citizen, production and irrigation water, biological habitat, flood mitigation and water storage [49]. The expansion of urban commercial land 
led to the decline of water-holding capacity of West Lake, resulting in the degradation of the ecosystem services it provided [50,51].

First of all, the emotional words with clear time records and descriptions of the area of the West Lake were evaluated to determine the two poles of the emotional vocabulary. During the Southern Han Dynasty, the West Lake was the largest in area and could provide sufficient freshwater resources for industrial production and agricultural irrigation for the city $[32,50]$. Besides, its water-holding capacity was sufficient to resolve the huge precipitation caused by typhoon and rainstorm. So West Lake in the Southern Han Dynasty was rated as Level 5 (Records 1-2).

By the time the Republic of China and the People's Republic of China were founded, the West Lake was no more than a spring and a ruined stone, and its ecological services lost, so it was rated as Level 1 (Records 7-8).

Integrity descriptive records are used to extend inferences about intermediate levels after determining the poles. By comparing the descriptions of the West Lake in the Qing Dynasty and the Republic of China, it can be seen that the West Lake in the Qing Dynasty, which was only about the size of a pond (about $10 \mathrm{~m}$ long), only could regulate the climate of a garden sized area. It was one level higher than the spring (only a weak source of water, almost dried up) [32,52], so West Lake in the Qing Dynasty was classified as Level 2 (Records 6-8).

From the historical records of the Qing Dynasty, the West Lake in the early Ming Dynasty was a famous scenic spot (about $200 \mathrm{~m}$ long) in Guangzhou [32,52]. During this period, it was a scenic spot that attracted a large number of citizens to visit because of its rich ecological diversity and cool regional climate, but he West Lake was silted up, and there were records of floods around it [32,50]. Its ability to hold water in response to flooding was reduced. So West Lake in Ming Dynasty was classified as Level 3 (Record 5).

In addition, according to the broader description of the West Lake in the Song and Yuan Dynasties (more than $200 \mathrm{~m}$ long, but less than $450 \mathrm{~m}$ long) and there were no records of silting and flooding [32,53], the West Lake in the Song and Yuan Dynasties can be classified as Level 4 (Records 3-4).

Table 2. Emotional vocabulary of the area of the West Lake.

\begin{tabular}{|c|c|c|}
\hline $\begin{array}{c}\text { Type of Emotional } \\
\text { Vocabulary }\end{array}$ & Emotional Vocabulary & $\begin{array}{c}\text { Level of Semantic } \\
\text { Differential }\end{array}$ \\
\hline \multirow{5}{*}{ Direct description } & $\begin{array}{l}450 \mathrm{~m} \text { (150 Zhang) long }{ }^{1} \text {; more than } \\
1550 \mathrm{~m} \text { (500 Zhang) in width }{ }^{2}\end{array}$ & 5 \\
\hline & $\begin{array}{l}\text { The west side silted up, leaving only the } \\
\text { east side }{ }^{3} ; \text { the West Lake shrank in area } \\
\text { in the Southern Song Dynasty }{ }^{4}\end{array}$ & 4 \\
\hline & The lake is silting in the throat ${ }^{5}$ & 3 \\
\hline & It is just a big pond in the school ${ }^{6}$ & 2 \\
\hline & $\begin{array}{l}\text { Only a few springs remain }{ }^{7} \text {; only ruined } \\
\text { stones remain } 8\end{array}$ & 1 \\
\hline Contextual description & $\begin{array}{l}\text { The scenic spots in Guangzhou }{ }^{9} \text {; not as } \\
\text { broad as in the Song and Yuan Dynasties } \\
10 \text {; take a boat on the lake }{ }^{11}\end{array}$ & - \\
\hline
\end{tabular}

2.2.4. Correlation Analysis of Climate Change and Natural, Economic, and Cultural Systems

Based on the SD, the semantic intensity correlation analysis matrix of climate change and natural, economic, and cultural systems was constructed. Through the analysis of the long-term correlation analysis among the four groups of data and the comparison of the correlation coefficient changes in multiple cycles [54], the resilience change process of the 
Yudai Trench historic urban landscape was further analyzed in a quantitative manner, and the correlation between the different systems was explored (more data can be found in Appendix C).

\subsection{Materials and Sources}

(1) Climate change data

There are abundant records of meteorology and phenology from ancient times to the present in Chinese historical documents. Many scholars have carefully sorted out climate change based on historical documents and further explored the relationship between climate change and urban construction, cultural and economic development, resource utilization, and other different contents. Zhu sorted the climate change data in China over the past five thousand years into the archaeological period, the phenological period, the chronicle period, and the instrumental observation period, which provides a solid theoretical basis for academic research on climate change [55]. Ge et al. reconstructed the sequence of temperature changes in China in the past 2000 years by using natural evidence such as tree rings and ice cores [56,57]. Wei et al. [58-60] summarized the impact of climate change on fiscal balance. These scholars' detailed analyses of climate change include the data of national temperature changes and the data of climate differences between the south and the north, which provides a rich database for the analysis of national climate change. In this paper, the temperature departure data are used to represent the climate change between the years 1000 and 2000, and the data are summarized from the research paper of Ge [57] (temperature departure data can be found in Appendix C).

(2) Historical Records of Yudai Trench historic urban landscape

In this study, a total of 212 historical records related to the Yudai Trench historic urban landscape were collected. These records come from 29 historical documents about the historical development of Guangzhou and 30 periodical papers on the historical research of Guangzhou. All of these sources are written by well-known scholars of Guangzhou's history. Many of the books are housed in the government's Local Records Office, where they are preserved as official documents and are often cited in important academic studies. In addition, different local records show a strong convergence in the description of the Yudai Trench's conditions at the same period, which can reflect the truthfulness of the historic information to a great extent; records or conclusions with many references allow more authority to be attributed to similar descriptions from other points of view [58]. All of the above conforms with the textual research published by historians over different eras regarding the Yudai Trench historic urban landscape, and thus the historical records extracted from those papers can meet the SD requirements.

\section{Results}

\subsection{Yudai Trench Historic Urban Landscape Resisting Climate Change with Resilience}

There are two kinds of changes in the three systems of the Yudai Trench historic urban landscape according to the changes in temperature (Figure 3). First, natural, economic, and cultural systems show signs of decline as temperatures drop. Second, economic and cultural systems gradually improve as temperatures rise, while the natural curve does not rebound.

In period (a), the initial levels of the natural system, the economic system, and the cultural system were 4.67,3.60, and 2.33, respectively. After entering the period of temperature drop, the natural and economic system levels fell to 4.33 and 3.00, respectively, due to water body siltation and market shrinkage caused by the war [32,61]. The rise in the cultural system is because the war promoted the initial establishment of Lingnan literature, which played a role in improving the level of the cultural system [53].

In period (c), the initial levels of the natural, economic, and cultural systems were $3.00,4.40$, and 4.33, respectively. After entering the period of temperature drop, the natural and economic systems were silted up, resulting in the loss of commercial location 
advantages [32,61]. Natural and economic declined to 2.67 and 3.60, respectively. The cultural system was affected by the economy, and the cultural industry did not develop well. Meanwhile, the South Park was gradually abandoned, and the level dropped to $3.00[33,40]$.

In period (e), the initial levels of the natural, economic, and cultural systems were $2.67,4.60$, and 4.00, respectively. After entering the period of temperature drop, the river landscape showed further atrophy. The commercial context around the water system gradually declined and moved inland $[32,53]$. This resulted in the natural and economic system levels falling to 2.33 and 3.20 , respectively. The steady development of (e) is attributed to the activity of the Lingnan literati, who created many poems around the Nanyuan Garden in the context of climate change and economic recession [33].

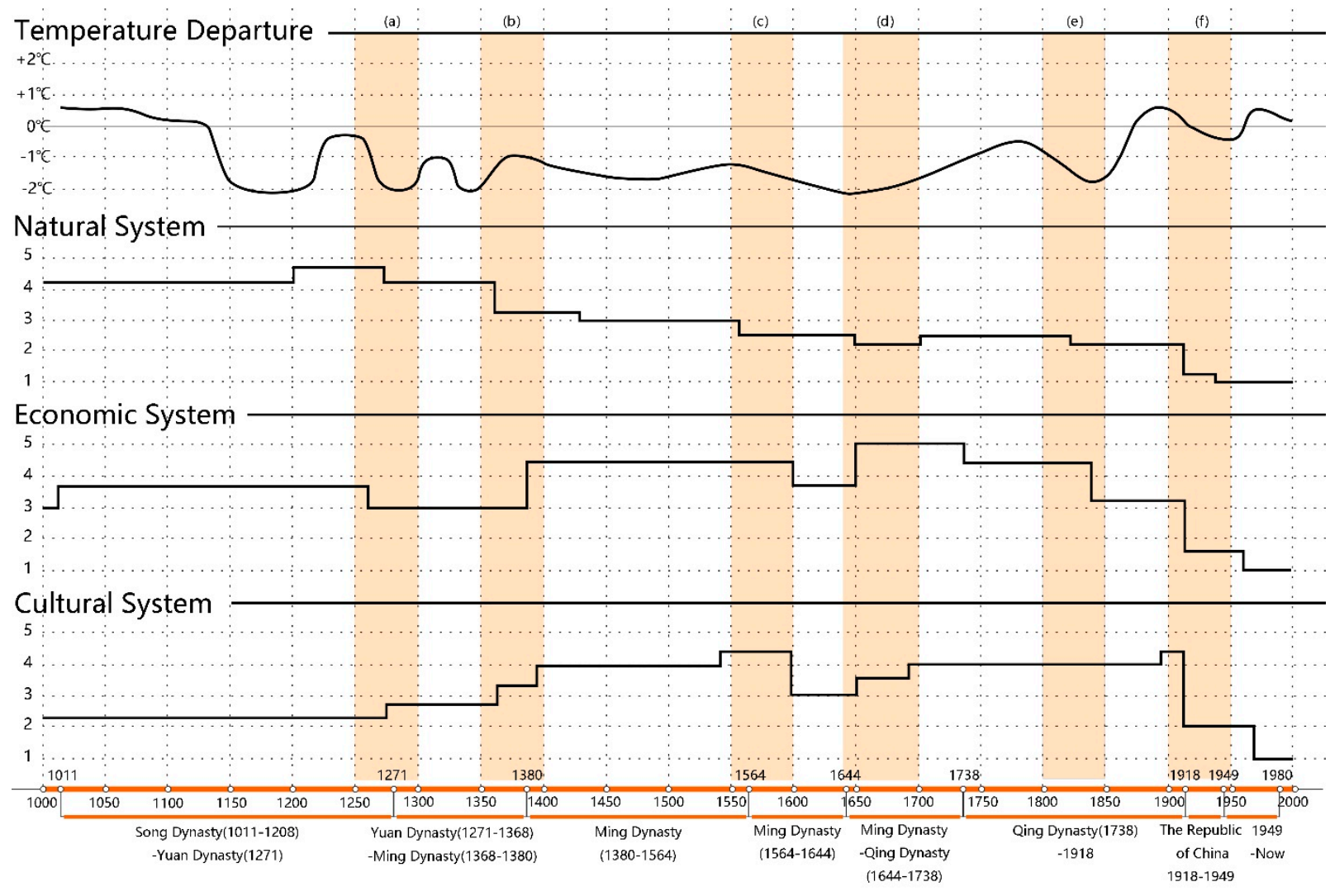

Figure 3. Temperature change curves and the intensity of natural, economic, and cultural systems' semantic change.

In period (f), the initial levels of the natural, economic, and cultural systems were $2.33,3.20$, and 4.33 , respectively. After entering the period of temperature drop, the water landscape disappeared completely, and the level dropped to 1.00 [32]. Businesses that rely on the water system were on the verge of bankruptcy, falling to 1.60 [32,33]. Due to cultural and economic similarities, the war caused great damage to the South Garden and literary creation, dropping to 2.00 [33].

By comparing the four time periods (a), (c), (e), and (f), it was found that the decline time of all three systems occurred within 50 years after the temperature change reached the inflection point. When the temperature dropped to nearly the lowest point, the development of each system tended to be stable, and the level of each system in this stationary stage was not lower than 2.00 .

In period (b), the initial levels of the natural system, the economic system, and the cultural system were $4.33,3.60$, and 2.67, respectively. After entering the period of temperature rise, the economic and cultural system developed rapidly in a stable social atmosphere and reached higher levels of 4.40 and 4.00 , respectively [32,33]. However, the rapid expansion 
of commerce in this period occupied the water landscape, resulting in the natural system's level falling to 3.33 [32].

In period (d), the initial levels of the natural system, the economic system, and the cultural system were 2.67, 3.60, and 3.67, respectively. After entering the period of temperature rise, the salt transportation industry developed further and promoted the development of surrounding businesses [32,53]. A large number of wealthy merchants gathered and introduced Western art and creative techniques, helping to improve the cultural system. The economic and cultural levels were 5.00 and 4.00, respectively. However, rich merchants filled in water to make land, which deteriorated the natural system and reduced its level to 2.33 [32].

Comparing (b) and (d), universality occurred when the temperature changed after a minimum of inflection point, and the economic and cultural systems showed rapid recovery in 50 years, and the economic and cultural levels rose back to 4.00 or above. Therefore, it can be seen that the Yudai Trench historic urban landscape has certain resilience in the face of the impact of temperature drops. It maintained a relatively low level of stable development under this impact, which persisted until the arrival of the recovery period when it began to regain its vitality.

\subsection{Correlations between Natural, Economic, and Cultural Systems}

The natural, economic, and cultural systems of the Yudai Trench historic urban landscape show correlations. The following will illustrate the correlation between the three systems in terms of periodicity and interaction.

\subsubsection{Periodic Changes with Temperature Changes among Natural, Economic, and Cultural Systems}

Due to the impact of temperature changes outside the system of the Yudai Trench historic urban landscape (Figure 3), the changes of the three systems are closely related and periodic. Comparing time periods (a) and (b) and (c) and (d) as groups, it was found that every time the temperature passed the inflection point, the levels of the natural, economic, and cultural systems decreased accordingly. This decline lasted for about 50 years, and over the following 50 years all three systems leveled off. Until the temperature again reached the inflection point of warming, the level of the economic and cultural systems began to rise, and the rise continued for about 50 years.

Therefore, it can be seen that the Yudai Trench historic urban landscape had a change period of about 150 years under the impact of temperature change, from descending to stable, and then rising, which took about 50 years for the different stages. Period (f) is distinct, because it falls within a cycle of rising temperatures without an upturn in the economic and cultural systems. Compared with the previous period, the Yudai Trench historic urban landscape gradually recovered in the face of climate change. However, after (f), each system began to decline rapidly, and the historic urban landscape also disappeared rapidly $[32,53]$. This means that there is a certain limit to the resilience of the Yudai Trench historic urban landscape. When it exceeded the limit, its resilience was destroyed and led to its own disappearance.

\subsubsection{Interaction between the Natural, Economic, and Cultural Systems}

There is an interaction between the natural, economic, and cultural systems. From the above analysis of the periodicity of the natural, economic, and cultural systems, it can be seen that there was a mutual effect among the three systems, which jointly withstood the impact caused by temperature changes outside the system and stabilized the development of the Yudai Trench historic urban landscape. Within the system, the interaction is reflected in the influence of the indexes on the system. Taking the influence of the width of the Yudai Trench on the systems as an example, the interaction of specific index is expounded (Figure 4).

In the time period $(\mathrm{g})$, the mouth of the Yudai Trench began to silt up, and the natural curve declined to 4.33. Due to the war, the number of shops in the main commercial 
street decreased significantly, and import and export trade shrank, but business did not completely disappear, so the economic level declined to 2.00 [32,33]. However, at the same time, the war promoted a rise in patriotic cultural activities; passionate patriotic poetry creation around the Nanyuan Garden was high, and the cultural curve rose to 4.00 [32,33].In the period of (h), the Yudai Trench was further narrowed to only $15 \mathrm{~m}$ (5 Zhang) wide, and the natural, economic, and cultural systems all fell to 2.67, 3.60, and 3.00, respectively [32]. During the period (i), the Yudai Trench eventually disappeared into water without a source, and the three systems were greatly reduced to the level of 1.00 due to the impact of pollution and war [32,62].

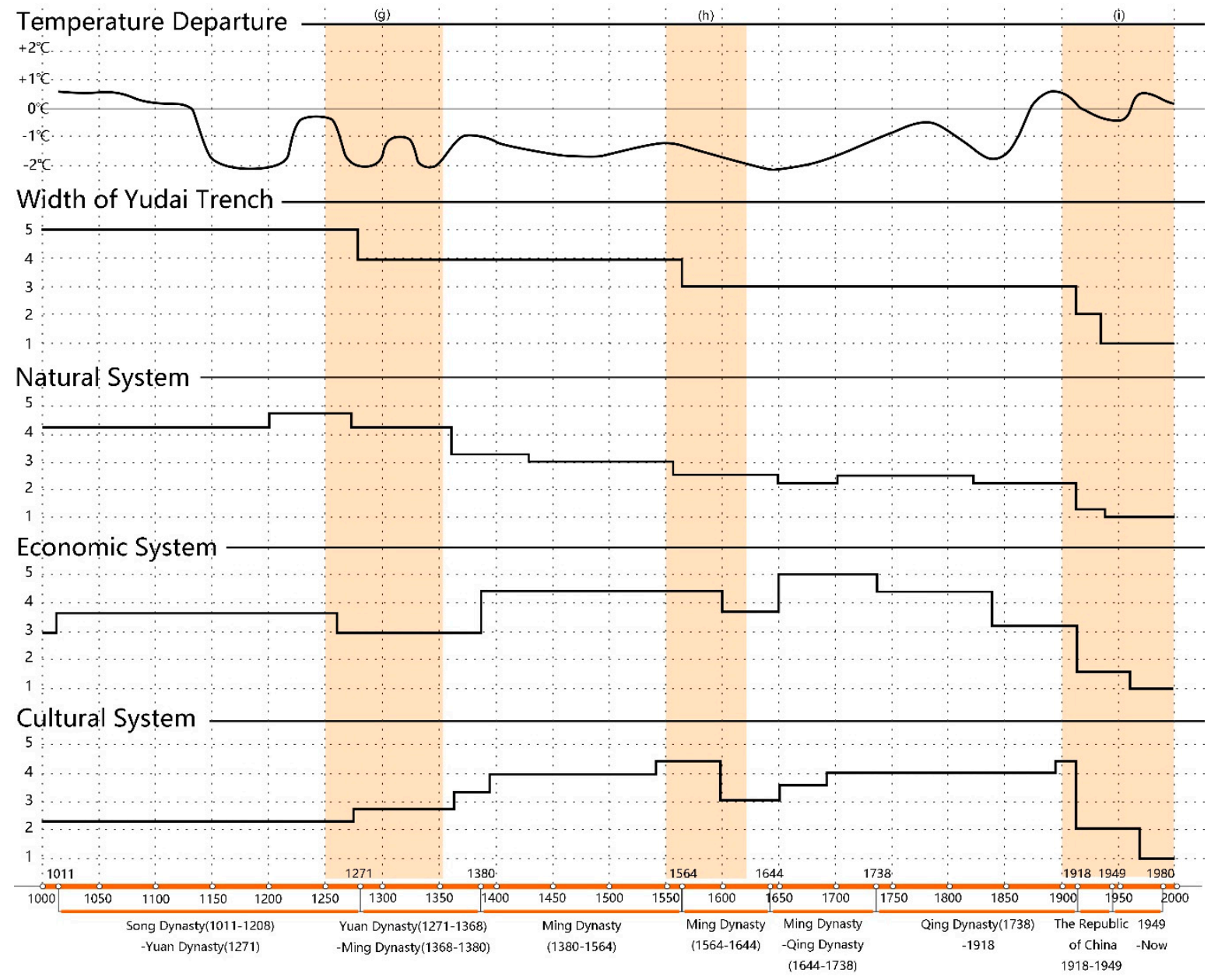

Figure 4. The curves of the width of Yudai Trench and the semantic intensity of the natural, economic, and cultural systems.

Throughout the 1000 years, the curves of the three systems decreased as the width of the Yudai Trench narrowed. When the Yudai Trench disappeared, the three systems reached the lowest level in the process of development. By analyzing the process of the three systems affected by the change of Yudai Trench width, it can be seen that the curve changes of three systems have a certain effective time and mutual influence. When the width of the Yudai Trench becomes narrow, the West Lake and Nanhao Trench connected with Yudai Trench are silted up, the natural system gradually weakens over 100 years. Affected by the siltation and increasingly serious pollution of water landscape, the economic system developed by water transportation declines rapidly over $75-100$ years. The cultural system is limited by the natural landscape and economic development, and gradually weakens over 75 years. 


\subsection{The Dominance and Priority of Natural Systems in Resilience Change}

The natural system has dominance and priority in the three systems, and it is the key force of resilience of Yudai Trench historic urban landscape. In comparison with the cultural and economic curves, the natural curve continues to decline. However, the cultural and economic curves have multiple rebound stages, and the change times of the curve do not coincide, indicating that the change in the cultural curve and economic curve is not the main reason for the change in the natural curve $[63,64]$ (Figure 3). The natural curve can be compared with the curve changes of the width of Yudai Trench, the area of the West Lake, and the volume of the Nanhao Trench, indicating a significant synchronous change relationship (Figure 5). By comparing the time periods (n), (o), (p), (q), and (r), it can be concluded that when the temperature drops, the three indexes of the Yudai Trench, West Lake, and Nanhao Trench will decrease to different degrees. Thus, the natural system is the first system to respond to climate change.

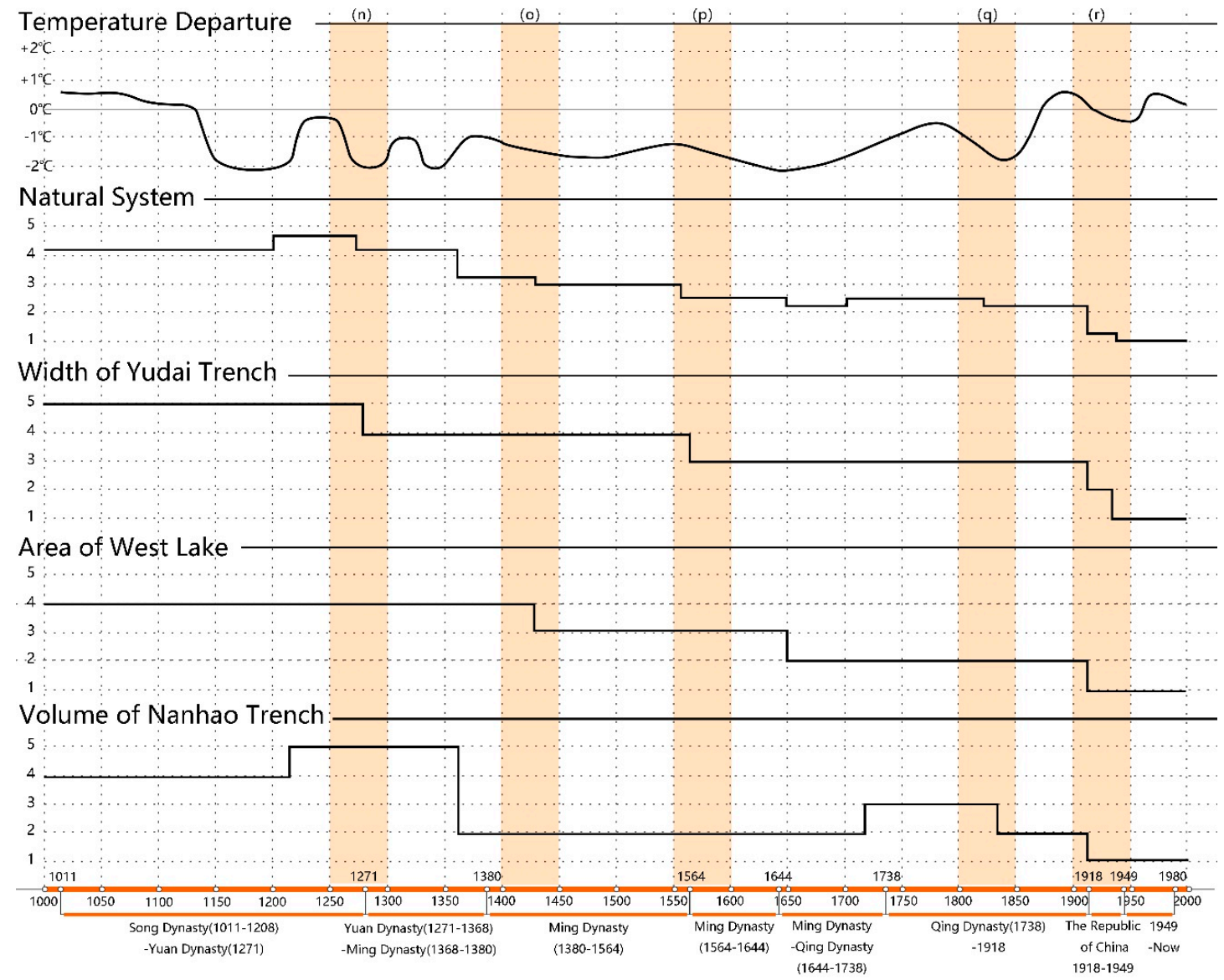

Figure 5. Curve of the natural system of the Yudai River coastal historic urban landscape.

In order to further analyze the dominance of the three systems, sections of the curve level's decline in the three systems were intercepted for comparative analysis. By comparing the periods of $(\mathrm{s}),(\mathrm{t}),(\mathrm{u})$, and $(\mathrm{v})$, it was found that in the section where the natural curve declines, the corresponding sections of various indicators of the economic system all decline to different degrees (Figure 6). However, the timing of the changes is nearly synchronous, making it difficult to tell which system is dominant.

Therefore, the reasons for this change were explored. The five indexes of the economic system depend on the development of the Yudai Trench to different degrees. The prosperity of these five indexes depends on the development of two functions: water transportation and trade. The water transportation and trade functions of Guangzhou City used the natural systems of the Yudai Trench, West Lake, and Nanhao Trench. For example, from 
1900 to 1950, the Yudai Trench was silted away, the West Lake was only a spring, and the Nanhao Trench became a dark canal. All three could no longer provide shipping; water transportation and trade functions were lost, and the economy along its coast declined significantly. In summary, when the natural system declines, it affects the water transportation and trade functions, and then causes the economic system to decline. Therefore, the natural system has dominance.

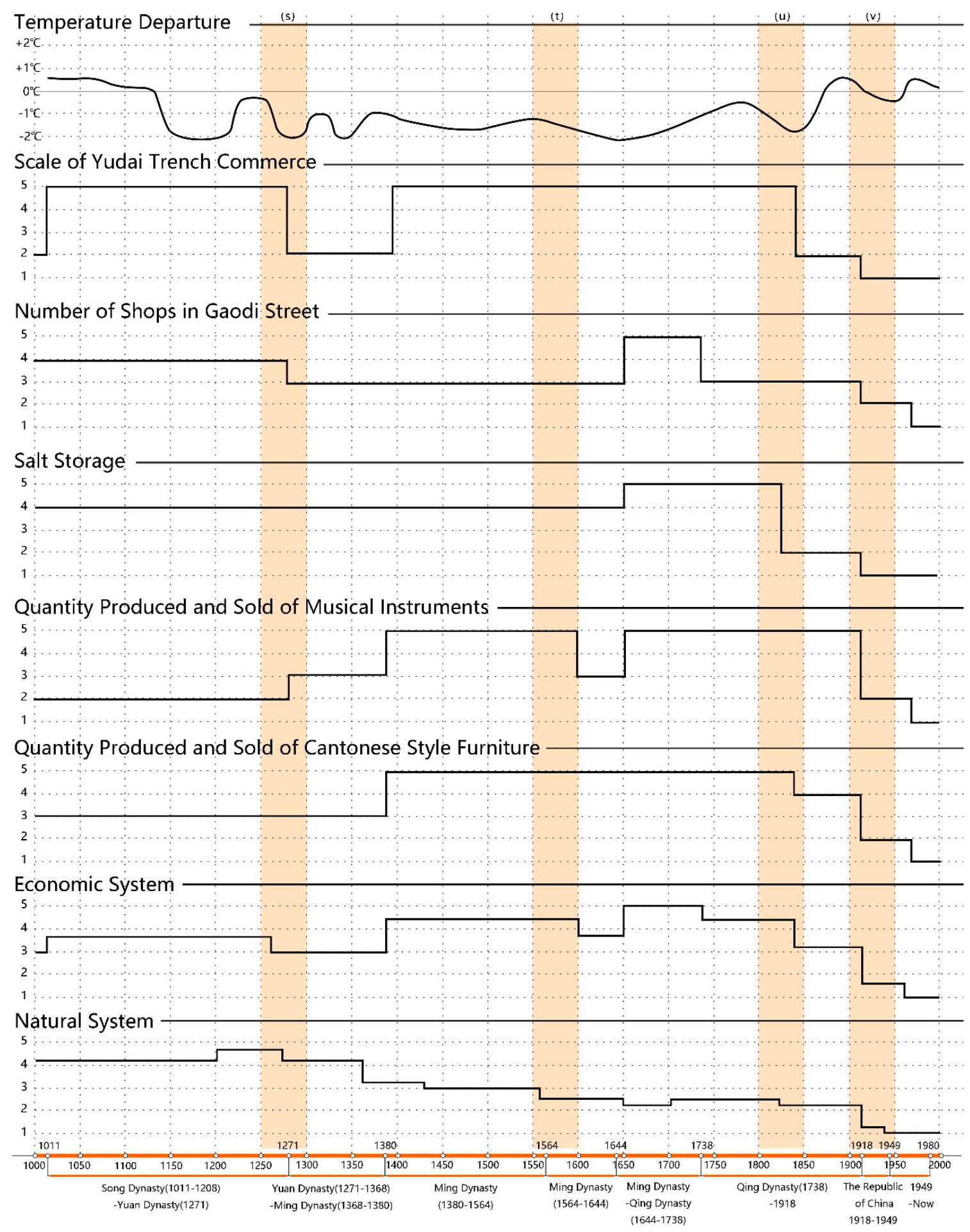

Figure 6. Curves of the natural and economic systems' semantic strength curve contrast. 
By comparing the time periods $(w),(x)$, and $(y)$, it was found that the commonality is that the natural curve declines over a certain time period, and the indicators of the cultural system all decline to different degrees in the corresponding time period (Figure 7). Among them, the changes in musical instruments and Cantonese-style furniture are consistent with the economic system, so it is difficult to distinguish. However, the decline of the Nanyuan Garden occurred in the sequence after the decline of the natural system. It can be seen that the change of the natural system preceded that of the cultural system, which has priority.

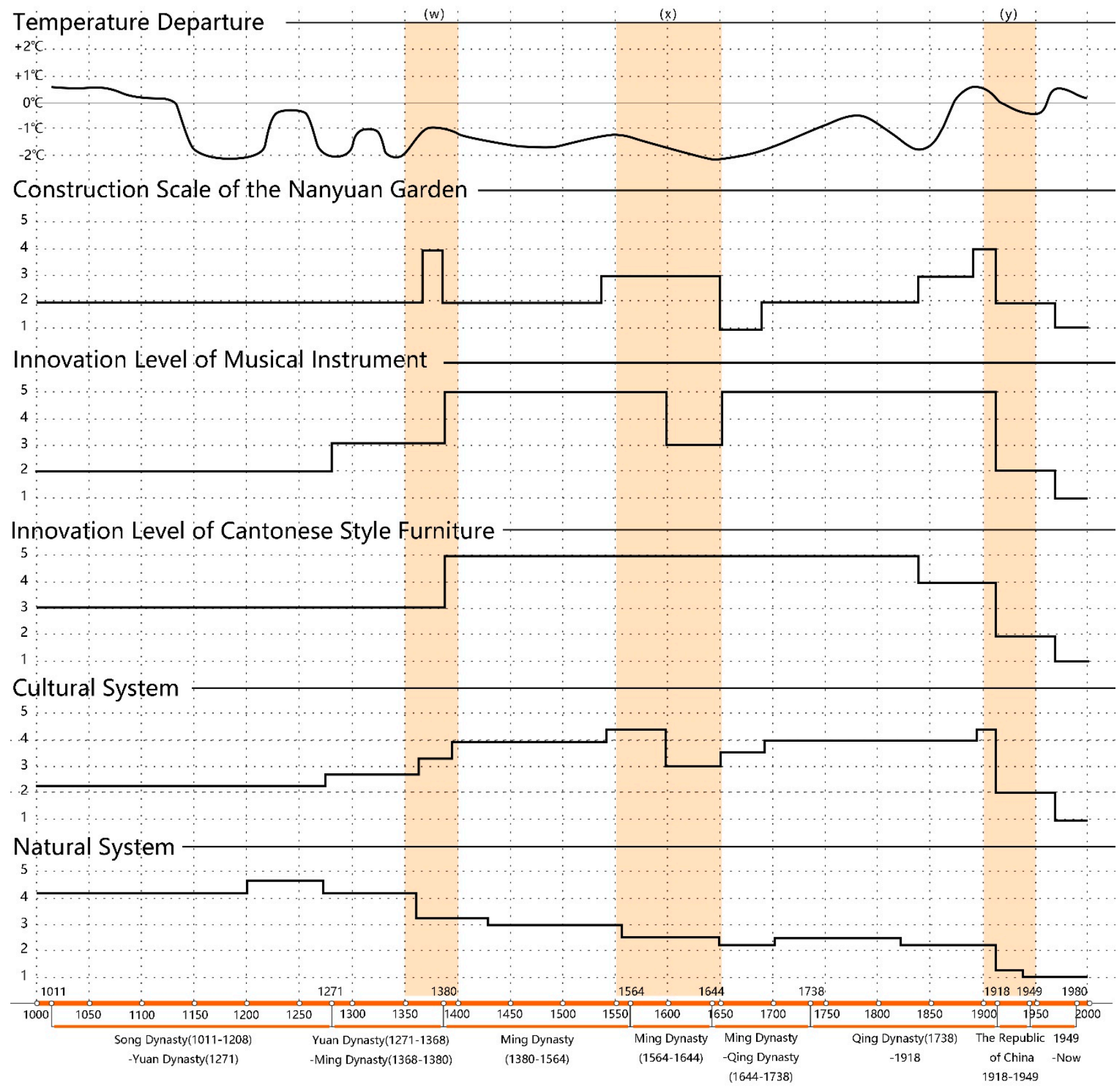

Figure 7. Curves of the natural and cultural systems' semantic strength curve contrast.

Therefore, the above result regarding the resilience of the historic urban landscape can be further explored. When the damage to the natural system reaches the maximum, the resilience of Yudai Trench historic urban landscape is destroyed, leading to its disappearance. The natural system was the source of the cultural and economic system changes, with the two characteristics of dominance and priority, and it was the key force in the resilience of the Yudai Trench historic urban landscape. 


\subsection{Resilience Change Characteristics of the Yudai Trench Historic Urban Landscape \\ 3.4.1. The Long-Term and Short-Term Changes of the Resilience of the Yudai Trench} Historic Urban Landscape

The results of the correlation analysis provide richer quantitative support for exploring the resilience change of the Yudai Trench historic urban landscape. Firstly, the correlation analysis was carried out to explore the long-term development characteristics of resilience affected by temperature change. Then, we analyzed the 150-year periods which are composed of the time periods (a)-(f), such as the late Yuan and early Ming Dynasty (1250-1400 years), the late Ming and early Qing Dynasty (1550-1700 years), and the Qing Dynasty to the early founding of the People's Republic of China (1800-1950 years), and we summarized the short-term change characteristics of resilience affected by temperature.

In the long-term development of the Yudai Trench historic urban landscape, there is a negative correlation between temperature changes and the natural system, a negative correlation between temperature changes and the cultural system, positively correlation between natural systems and economic systems, and a positive correlation between the economic and cultural system (Table 3).

Table 3. Long-term correlation analysis of temperature change and natural, economic, and cultural systems.

\begin{tabular}{cccc}
\hline & Temperature Change & Natural System & Economic System \\
\hline Temperature Change & 1.000 & - & - \\
Natural System & $-0.211^{* * *}$ & 1.000 & - \\
Economic System & -0.483 & $0.197^{* * *}$ & - \\
Cultural System & $-0.427^{* * *}$ & -0.192 & - \\
\cline { 2 - 3 }
\end{tabular}

Note: ${ }^{* * *} p<0.01$; more data can be found in Appendix C-Table A8.

The negative correlation between temperature changes and the cultural system reflects that a temperature decrease stimulates the development of human culture in response to climate disasters [65]. In response to the temperature decrease, modified crops planting way and the invention of living tool can help people get more materials to survive [65]. This provided the industrial basis for the manufacture of Cantonese furniture and Musical Instruments [40]. In addition, the serious social problems brought by the temperature decrease, such as the price rise, the outbreak of wars and so on, have worsened people's living condition [66]. Literary creation provides spiritual support for Guangzhou citizens living in difficult conditions [33].

In addition, the results also reflect the difference between the impact of temperature on natural systems and the impact of temperature on economic and cultural systems. The negative correlation coefficient between natural system and temperature change is significant [67]. This suggests that natural systems can provide more effective defenses against the negative effects of temperature change.

A horizontal comparative analysis with a 150-year change period showed that there was a transition process from a negative correlation to a positive correlation between the natural system and the economic system, which further confirms the results that the natural system plays a key role in the resilience of the historic urban landscape (Table 4).

In the period from 1250 to 1400 , there was a negative correlation between the natural system and the economic and cultural system. During this period, the ecosystem services provided by the natural systems were sufficient to withstand the impact of temperature change and to support the rapid development of economic and cultural systems. In the period from 1550 to 1700 , the natural system declined, the ecosystem services weakened, and the ability to support the economy and culture greatly weakened. At the same time, there was a positive correlation between the natural and cultural systems, which indicates that the natural system's ability to resist temperature changes was weakened, and the decline of the cultural systems was reflected first. In the period from 1800 to 1950, there was a positive correlation between the natural system and the economic and cultural systems. 
The natural system collapsed, and the ability to resist was lost, leading to a collapse of the economic and cultural systems.

Table 4. Short-term correlation analysis of temperature changes and natural, economic, and cultural systems.

\begin{tabular}{|c|c|c|c|c|c|c|c|c|c|c|c|c|}
\hline \multirow{2}{*}{$\begin{array}{l}\text { Period of } \\
\text { Time }\end{array}$} & \multicolumn{4}{|c|}{$1250-1400$} & \multicolumn{4}{|c|}{$1550-1700$} & \multicolumn{4}{|c|}{ 1800-1950 } \\
\hline & $\begin{array}{l}\text { Temperature } \\
\text { Change }\end{array}$ & $\begin{array}{l}\text { Natural } \\
\text { System }\end{array}$ & $\begin{array}{l}\text { Economic } \\
\text { System }\end{array}$ & $\begin{array}{l}\text { Cultural } \\
\text { System }\end{array}$ & $\begin{array}{l}\text { Temperature } \\
\text { Change }\end{array}$ & $\begin{array}{l}\text { Natural } \\
\text { System }\end{array}$ & $\begin{array}{l}\text { Economic } \\
\text { System }\end{array}$ & $\begin{array}{l}\text { Cultural } \\
\text { System }\end{array}$ & $\begin{array}{l}\text { Temperature } \\
\text { Change }\end{array}$ & $\begin{array}{l}\text { Natural } \\
\text { System }\end{array}$ & $\begin{array}{l}\text { Economic } \\
\text { System }\end{array}$ & $\begin{array}{l}\text { Cultural } \\
\text { System }\end{array}$ \\
\hline $\begin{array}{l}\text { Temperature } \\
\text { Change }\end{array}$ & 1.000 & - & - & - & 1.000 & - & - & - & 1.000 & - & - & - \\
\hline $\begin{array}{l}\text { Natural } \\
\text { System }\end{array}$ & $\underset{* * *}{-0.662}$ & 1.000 & - & - & $\underset{* * *}{0.658}$ & 1.000 & - & - & -0.494 & 1.000 & - & - \\
\hline $\begin{array}{l}\text { Economic } \\
\text { System }\end{array}$ & $\underset{* * *}{0.496}$ & $\underset{* * *}{-0.343}$ & 1.000 & - & $-\underset{* * *}{-0.149}$ & $-\underset{* * *}{-0.691}$ & 1.000 & - & $\underset{* * *}{-0.350}$ & $\underset{* * *}{0.910}$ & 1.000 & - \\
\hline $\begin{array}{l}\text { Cultural } \\
\text { System }\end{array}$ & $\underset{* * *}{0.695}$ & $\underset{* * *}{-0.933}$ & $\underset{* *}{0.603}$ & 1.000 & $\underset{* * *}{0.624}$ & $\underset{* * *}{0.041}$ & $\underset{* * *}{0.619}$ & 1.000 & $-\underset{* * *}{-0.504}$ & $\underset{* * *}{0.944}$ & $\underset{* *}{0.805}$ & 1.000 \\
\hline
\end{tabular}

Note: ${ }^{* *} p<0.05 ;{ }^{* *} p<0.01 ;$ more data can be found in Appendix C-Table A9.

In conclusion, the natural system is the key force in historic urban landscape resilience. Temperature is one of the influencing factors, and human activities may also have an influence on historic urban landscape resilience. In addition, the collapse of the natural system will lead to the disappearance of the resilience of historic urban landscapes. The following will further explore the resilience limit of the natural system.

\subsubsection{Natural Landscape Resilience Limit of the Yudai Trench Historic Urban Landscape}

The natural landscape is the main component of the natural system of the Yudai Trench historic landscape, and it is the key force of resilience. There is a limit to its resilience, and when the natural landscape is destroyed up to a certain limit, the resilience will no longer exist. Temperature change has a significant impact on the growth, development, and diversity of plants in natural landscapes, as well as on water quality and quantity in water system landscapes [68]; at the same time, natural disasters such as drought and flood may occur [55]. The following will trace how natural landscapes resist the impact of temperature change and the process of resilience collapse of natural landscapes.

(1) Late Yuan Dynasty and Early Ming Dynasty (1250-1400)

In this period, the year 1250 was one of the warm peaks in China within a period of nearly 2000 years. After passing the inflection point of the warm front, the temperature began to drop rapidly and entered a period of extreme drought [57]. Falling temperatures and an arid climate simultaneously reduce urban precipitation and available water resources, thus affecting urban residents' water supply required for living and production. During this period, the culture and economy were severely impacted by temperature changes and wars. However, in the early Ming dynasty, the water sources and water-holding capacity of the water system landscapes such as those of the Yudai Trench, West Lake, and Nanhao Trench were still good, assuming the function of water storage and water supply and alleviating the decrease in available water resources at this time. From 1350 to 1400, the temperature rose and precipitation increased, which alleviated the drought. The abundant water sources and a wide enough water body provided the foundation for the recovery of commerce along the Yudai Trench historic urban landscape, and then the cultural and economy recovered rapidly in the following 50 years. In addition, due to the rapid cultural and economic recovery, the city's demand for resources and environment greatly increased, which led to the reclamation of the Yudai Trench, West Lake, and the Nanhao Trench in the early Ming Dynasty [57,58].

(2) Late Ming Dynasty and Early Qing Dynasty (1550-1700)

The period from 1600 to 1650 was a period of frequent occurrence of extreme drought [57]. Subsequently, 1650-1700 was considered to be the coldest period in China, in which severe cold waves in 1654 and 1676 even caused ice and snow disasters in tropical and subtropical areas of China [55,57]. During these 150 years, the temperature decline did not increase 
much, and the temperature remained low for a long time. The cold climate led to frequent droughts in Guangzhou, less available water resources, and crop failure, which led to a series of impacts on cultural and economic stability. The Ming Dynasty witnessed the cutting off of the water sources of the Yudai Trench, West Lake, and Nanhao Trench. The Nanhao Trench almost ceased to exist, and the area of the West Lake was greatly reduced. The Yudai Trench was trapped by the expansion of the city and was narrow enough to use a bridge to cross the water. The resilience of these three water system landscapes had to cope with the impact of temperature change, and the cultural economy experienced a hierarchical decline. Then, after passing the turning point of the cold front in 1654, due to the slow rise in temperature and damage to the natural landscape of the Yudai Trench historic urban landscape, the cultural and economic recovery range was far less than that of the late Yuan Dynasty and early Ming Dynasty.

(3) Qing Dynasty to the beginning of the founding of China (1800-1950)

In contrast to the above two groups of time periods, this group reveals the reasons for the collapse of the historic urban landscape. During 1801-1850 and 1901-1950, extreme flood disasters occurred frequently. Meanwhile, the 19th century (1800-1900) was the coldest period second only to the 17th century (1600-1700) [55]. However, after the cold front, China immediately entered a rapid warming period in the 20th century $[57,58]$. Flood disasters and temperature drops from 1800 to 1900 had a certain impact on the cultural and economic systems. To make matters worse, from 1900 to 1950, floods occurred frequently and the temperature rose rapidly. As a result, the atmospheric water cycle accelerated and precipitation increased, which greatly increased the demand for urban flood discharge and drainage capacity. In contrast to the past recovery periods, the Nanhao Trench and West Lake almost disappeared at this time, and their functions of water storage and flood discharge ceased to exist, while the Yuzai Trench was only $6 \mathrm{~m}$ (2 Zhang) wide with multiple silting. The decrease in water source and capacity made it difficult to supply water for daily life and production. Meanwhile, the narrow water landscape worsened the commercial environment along the coast, leading to cultural and economic decline. The clogged water system landscape, under the rapidly rising temperature, became a fertile soil for the growth of bacteria, insects, and rats, further aggravating the collapse of the resilience of the Yudai Trench historic urban landscape.

In summary, a good natural landscape provided solid resilience for the Yudai Trench historic urban landscape (Table 5). In the period from the end of Yuan Dynasty to the beginning of the Ming Dynasty and from the end of Ming Dynasty to the beginning of the Qing Dynasty, facing the impact of climate change on all systems, it was able to resist well and cooperate with the rapid recovery of all systems. Even when the level of Nanhao Trench dropped below 3.00, it was still able recover gradually through the ecosystem services provided by the Yudai Trench and West Lake. However, when the level of the natural landscape dropped below 3.00, the resilience of the historic urban landscape was irreversibly damaged, and the resilience that supported its stable development collapsed, leading to the disappearance of the Yudai Trench historic urban landscape in the city. 
Table 5. Semantic intensity change of the natural landscape and economic and cultural systems.

\begin{tabular}{|c|c|c|c|c|c|c|c|c|c|}
\hline \multirow[b]{2}{*}{$\begin{array}{l}\text { Period of } \\
\text { Time }\end{array}$} & \multicolumn{3}{|c|}{ Yuan Dynasty and Early Ming Dynasty } & \multicolumn{3}{|c|}{ Late Ming and Early Qing } & \multicolumn{3}{|c|}{ Qing Dynasty until the Founding of China } \\
\hline & $\begin{array}{c}\text { Decline } \\
\text { Period } \\
(1250-1300)\end{array}$ & $\begin{array}{c}\text { Stable } \\
\text { Period } \\
(1300-1350)\end{array}$ & $\begin{array}{c}\text { Recovery } \\
\text { Period } \\
(1350-1400)\end{array}$ & $\begin{array}{c}\text { Decline } \\
\text { Period } \\
(1550-1600)\end{array}$ & $\begin{array}{c}\text { Stable } \\
\text { Period } \\
(1600-1650)\end{array}$ & $\begin{array}{c}\text { Recovery } \\
\text { Period } \\
(\mathbf{1 6 5 0 - 1 7 0 0 )}\end{array}$ & $\begin{array}{c}\text { Decline } \\
\text { Period } \\
\text { (1800-1850) }\end{array}$ & $\begin{array}{c}\text { Stable } \\
\text { Period } \\
(1850-1900)\end{array}$ & $\begin{array}{c}\text { Collapse } \\
\text { Period } \\
(1900-1950)\end{array}$ \\
\hline $\begin{array}{l}\text { Width of } \\
\text { Yudai Trench }\end{array}$ & $5 \rightarrow 4$ & 4 & 4 & $4 \rightarrow 3$ & 3 & 3 & 3 & $3 \rightarrow 2$ & $2 \rightarrow 1$ \\
\hline $\begin{array}{c}\text { Area of West } \\
\text { Lake }\end{array}$ & 4 & 4 & 4 & 3 & 3 & $3 \rightarrow 2$ & 2 & 2 & $2 \rightarrow 1$ \\
\hline $\begin{array}{l}\text { Volume of } \\
\text { Nanhao } \\
\text { Trench }\end{array}$ & 5 & 5 & $4 \rightarrow 2$ & 2 & 2 & 2 & $3 \rightarrow 2$ & 2 & $2 \rightarrow 1$ \\
\hline $\begin{array}{l}\text { Economic } \\
\text { System }\end{array}$ & $3.6 \rightarrow 3$ & 3 & $3 \rightarrow 4.4$ & $4.4 \rightarrow 3.6$ & 3.6 & $3.6 \rightarrow 5$ & $4.6 \rightarrow 3.2$ & 3.2 & $3.2 \rightarrow 1.6$ \\
\hline $\begin{array}{l}\text { Cultural } \\
\text { System }\end{array}$ & $2.3 \rightarrow 2.67$ & 2.67 & $2.67 \rightarrow 4$ & $4.33 \rightarrow 3$ & 3 & $3 \rightarrow 4$ & 4 & $4 \rightarrow 4.33$ & $4.33 \rightarrow 2$ \\
\hline
\end{tabular}

Note: The value of each system was obtained by calculating the mean value of semantic intensity value of each index of the system.

\section{Discussion}

4.1. Resilience to the Breakdown of the Yudai Trench Historic Urban Landscape as Result of the Collapse of the Natural Landscape

Guangzhou has concentrated rainfall in partial depression areas, and it suffers from frequent floods and typhoons. The natural landscape of the water systems, such as the Yudai Trench, Nanhao Trench, and West Lake, provides ecosystem services for the city, such as living water, safe harbors, disaster prevention, flood discharge, and so on. The more areas covered, the greater the amount of water storage capacity that can be obtained, and hence the greater the significance of the ecosystem services [57,58].

Due to the expansion of Guangzhou City in the Ming Dynasty [32,62], the water source of Wenxi was relocated, which cut off the main water source for the natural water landscape in the city. The Yudai Trench, West Lake, and Nanhao Trench were gradually silted up, and the water quality and capacity were no longer able to support the needs of the citizens for disaster prevention. In the 20th century, the Yudai Trench deteriorated into a gutter. During the rainy season, the stench is bad, and it turns into a pollution source. The Nanhao Trench was especially prone to flooding because of its low-lying terrain. All three have lost the ecosystem services they provided.

In addition, the degradation of the natural water landscape has had a negative impact on the economic and cultural development of the city from the aspects of water transportation and trade.

In terms of water transportation, Guangzhou was an important port city in ancient China, and the water system landscape constituted the transportation network between the interior and exterior of Guangzhou, forming the economic "artery" of Guangzhou [36]. Commercial transportation such as salt transportation and transportation for the wood processing industry have basic requirements for the water-holding capacity of the water landscape $[32,40]$. In the period of the Republic of China, the natural landscape shrank seriously, the water-holding capacity decreased, the salt merchants withdrew, the timber transportation disappeared, and the development of various industries fell rapidly over 50 years.

In terms of trade, the landscape of the water system provided a haven for ships and a place for trade [62]. The geographical advantage of proximity to the Pearl River bank facilitated the transportation of wood and other processed materials as well as the export of various products [33], thus promoting the riverside of Yudai Trench to become a gathering place of commercial premises. However, by the end of the Ming Dynasty, merchants on both sides were competing for land to fill trench. The body of the trench occupied only $15 \mathrm{~m}$ (5 Zhang); the function of the haven was lost, the location advantage was lost, and trade was reduced. In the Qing Dynasty, there were only $6 \mathrm{~m} \mathrm{(2} \mathrm{Zhang)} \mathrm{left} \mathrm{of} \mathrm{the}$ Yudai Trench; ships had difficulty passing through, and the trade center was transferred to the Pearl River, so the Yudai Trench lost its shipping and trade value [32]. As a result, the salt transportation industry, musical instrument workshops, and Cantonese furniture 
workshops that developed by relying on the advantages of Yudai Trench declined rapidly in $50-100$ years.

The natural landscape is a key force in the resilience of the Yudai Trench historic urban landscape. In the process of the disappearance of the Yudai Trench historic urban landscape, urban expansion blocked the river from providing water for the urban water landscape, leading to the gradual shrinkage and disappearance of the water system landscape. The shrinkage of the water landscape and the depletion of natural water resources weakened the ecological services provided by natural system and its supporting role in the sustainable development of economy and culture. In addition, pollution from domestic sewage to the surrounding environment of the water landscape further threatened people's life and health and property safety, reduced the quality of life, caused frequent occurrences of environment-induced diseases, and even affected cultural stability. The massive destruction of water quality and water-holding capacity of the natural landscape led to the collapse of resilience. Therefore, the Yudai Trench historic urban landscape encountered difficulty in coping with the impact from within and outside of the system, and finally ceased to exist.

\subsection{The Scenario of Guangzhou as Result of Resilience Development of the Yudai Trench Historic Urban Landscape}

By reviewing the disappearance of Yudai Trench historic urban landscape, it was found that the natural landscape, such as trenches, lakes, and rivers, has been seriously affected by human activities. In today's Guangzhou City, the prosperous water landscape is no longer visible. If the resilience of the Yudai Trench historic urban landscape had been valued by the citizens, what impact would it have had on urban development today?

First of all, if the Ming Dynasty had not cut off the Wenxi River water source, the West Lake and Nanhao Trench, which were narrow due to the war, would have been cleaned up in time to maintain good water quality. The quality and quantity of water used for production and living by the businesses and households along the coast would be sufficient to cope with the drought caused by temperature drops and would be able provide abundant resources for the rapid development of culture and economy.

During the period from the Ming Dynasty to the middle period of the Qing Dynasty, with the expansion of cities, the encroachment on the urban water system would be strictly restricted to ensure the quality of water sources and water-holding capacity. This measure would provide a solid foundation for waterborne transportation and waterborne trade, and also guarantee the functions of disaster prevention, drainage, and water storage provided by the water landscape. At the same time, the environment of public activities provided by the beautiful natural landscape would promote the occurrence of public activities and further promote the output of literary creation centered on the characteristics of water towns.

During the period from the late Qing Dynasty to the Republic of China, if the urban waterway network had been retained, the mode of freight trade would not have changed to land routes, thus forming a unique waterway transportation route and trade environment, which would add to the characteristics of the water town and the urban development of Guangzhou. The economic center would not migrate, but gradually expand, and form a commercial belt connected by the Yudai Trench, West Lake, and Nanhao Trench through waterways. The respective clear division of labor and diversified business forms would continue to inject impetus to economic development.

Since the founding of the People's Republic of China, urban temperatures have been rising rapidly. Through the conservation and renewal of the natural landscape along the Yudai Trench, a "cold bridge" in the city would be formed, which could alleviate the temperature rise and the urban heat island effect, providing habitats for the creatures in the city and enhancing biodiversity $[4,7]$. In addition, the unique water texture would provide a huge opportunity for the expansion of the city's tertiary industries, such as cultural tourism, wood cultivation experiences, and musical instrument workshop experiences.

Reviving the urban development process of Guangzhou in the past 20 years, the texture of the new commercial centers in Guangzhou, such as Pearl River New Town (Built 
in 2010) and Guangzhou International Financial City (under construction), and Fish Pearl Harbor (under construction), all imitate the texture of the Yudai Trench historic urban landscape. With transportation networks over land and water, the commercial layout is carried out along the coast with the natural landscape of the water system in a development context. In the scenario, the Yudai Trench historic urban landscape would continue to serve as the economic and cultural center of Guangzhou, providing excellent ecosystem services and a foundation for business development.

\subsection{Study Limitations}

In the context of high-density urban development, people tend to focus on the history, architecture, and culture of historic urban landscape and do not regard natural landscapes as a key force of resilience. Fully understanding and guaranteeing the dominance of natural landscape is conducive to the integration of natural ecological assets, artificial ecological assets, and intangible ecological assets [31], as well as to the enhancement of water conservation, stabilizing hydrology, constructing ecological networks, and regulating climate and other ecosystem services [31].

At the same time, the conservation and renewal planning of historic urban landscapes usually takes 20-25 years to formulate countermeasures. In the face of the internal and external impacts of rapid urbanization and climate change on the system, the maximum planning period of 25 years is not enough to cover a single period in the cycle. Therefore, it is still necessary to carry out a 50-150 years conservation and renewal strategy study on the historic urban landscape from the perspective of resilience.

This paper mainly analyzed the resilience of a disappeared historic urban landscape and explored the interaction mechanisms among various systems. This is the experience extraction of failed cases that have disappeared over the long course of history, and we focused on the static evaluation of resilience. The change process of resilience affected by temperature change presents a static causal change of "driver-response". In reality, the resilience of historic urban landscapes changes dynamically and is influenced by human and natural systems at different scales and in different times and spaces. Therefore, to further reveal the dynamic leading role of natural landscapes in different spatial and temporal scales of historic urban landscapes, it is beneficial to avoid damage to historic urban landscapes caused by high-density urban development.

\section{Conclusions}

In this study, a semantic differential analysis was used to analyze the historical records related to the Yudai Trench historic urban landscape and to explain the key force and mechanisms behind its resilience.

Firstly, the natural, economic, and cultural systems of the Yudai Trench historic urban landscape show a correlation. Among them, due to the impact of climate change, the three systems have a 150-year change cycle, which is divided into three stages of decline, stability, and recovery, with each stage lasting for 50 years. There is an interaction between the natural, economic, and cultural systems, which, together, can help resist the impact of climate change from outside the system and are restricted by the same factors.

Second, the natural system has dominance and priority. It is mainly affected by the temperature change, responds to temperature change first, and dominates over the cultural and economic changes.

Third, the natural landscape is a key force in the resilience of the Yudai Trench historic urban landscape. When the natural landscape is damaged, resilience collapses, leading to the decline and disappearance of historic urban landscapes.

Guangzhou has been a commercial and cultural center of South China since ancient times. The disappearance of its core historic urban landscape is of certain representative significance for the exploration of the role of historic urban landscapes in the sustainable development of the city. On the one hand, we can achieve an in-depth understanding of the changing rules of historic urban landscape resilience in China's first-tier cities. On the other 
hand, taking this counter example as a reference, people can draw historical experience from it to lead the sustainable development of the current urban historical landscape and provide reference suggestions for the urban construction of similar water towns.

Author Contributions: Conceptualization, W.G., Y.W. and G.C.; methodology, G.C. and Y.W.; resources, W.G., F.J. and Y.W.; data curation, G.C. and J.S.; writing-original draft preparation, W.G., G.C. and F.J.; writing-review and editing, G.C., J.S. and W.G.; supervision, W.G. and Y.W.; project administration, W.G. and Y.W.; funding acquisition, W.G. and Y.W. All authors have read and agreed to the published version of the manuscript.

Funding: This work was supported by the National Natural Science Foundation of China, grant number 51708227, and the National nature science foundation of China, grant number 51978479. The Research on database Construction of Historic Urban Landscape Features Based on Information Model Technology-A case study of Guangzhou of the Natural Science Foundation of Guangdong Province China, grant number 2017A030310461.

Institutional Review Board Statement: Not applicable.

Informed Consent Statement: Not applicable.

Data Availability Statement: The data presented in this study are available on request from the corresponding author. The data are not publicly available due to privacy reasons.

Conflicts of Interest: The authors declare no conflict of interest.

\section{Appendix A}

Table A1. Table of place names.

\begin{tabular}{|c|c|c|}
\hline Serial Number & Place Name & Description \\
\hline 1 & Yudai Trench & $\begin{array}{l}\text { Yudai Trench is a moat excavated from the east to the west during the } \\
\text { Song Dynasty, with the functions of shipping and disaster prevention. }\end{array}$ \\
\hline 2 & Qing Dynasty City Wall & $\begin{array}{l}\text { During the Qing Dynasty, the city wall of Guangzhou was divided } \\
\text { the city into inner and outer cities, and the outer city wall contained } \\
\text { the Yudai Trench. }\end{array}$ \\
\hline 3 & Gaodi Street & $\begin{array}{l}\text { Gaodi street has been prosperous since the Song Dynasty because of } \\
\text { the convenient shipping of the Yudai Trench. It is the freight trading } \\
\text { center of Guangzhou city. }\end{array}$ \\
\hline 4 & Haopan Street & $\begin{array}{l}\text { Haopan Street is a commercial street close to Yudai Trench, with } \\
\text { prosperous trade. }\end{array}$ \\
\hline 5 & Nanhao Trench & $\begin{array}{l}\text { Nanhao Trench was an important traffic waterway excavated during } \\
\text { the Song Dynasty. It was connected with the Yudai Trench and was } \\
\text { one of the most prosperous areas in Guangzhou City in the past. }\end{array}$ \\
\hline 6 & West Lake & $\begin{array}{c}\text { The West Lake, which was excavated from a tributary of the Wenxi } \\
\text { River at the end of the Tang Dynasty, carries the functions of a water } \\
\text { source, flood resistance and storage, fire and disaster prevention, } \\
\text { irrigation and shipping. }\end{array}$ \\
\hline 7 & Wenxi River & $\begin{array}{l}\text { The source of the Wenxi River was the Baiyun Mountain. Its east } \\
\text { tributary flowed from south to north through the small north gate, } \\
\text { and its west tributary was used as the water source of the West Lake. } \\
\text { In the Ming Dynasty, the water of Wenxi no longer entered the city, } \\
\text { but flowed away from the eastern wall. }\end{array}$ \\
\hline 8 & Nanyuan Garden & $\begin{array}{l}\text { Many poets gathered to set up the Nanyuan Garden because of the } \\
\text { prosperity of the Yudai Trench and created Lingnan poetry. }\end{array}$ \\
\hline 9 & The Pearl River & $\begin{array}{l}\text { The urban water system of the ancient city of Guangzhou eventually } \\
\text { converges into the Pearl River. }\end{array}$ \\
\hline
\end{tabular}




\section{Appendix B}

Table A2. Semantic differential analysis for the historical records of natural systems.

\begin{tabular}{|c|c|c|c|c|c|c|}
\hline \multicolumn{2}{|c|}{ Emotional Intensity } & 1 & 2 & 3 & 4 & 5 \\
\hline \multicolumn{2}{|c|}{ Overviews } & Extreme Poor & Poor & Medium & Good & Extreme Good \\
\hline \multirow{2}{*}{$\begin{array}{c}\text { Contextual } \\
\text { Description of } \\
\text { Natural System }\end{array}$} & $\begin{array}{l}\text { Natural } \\
\text { Resources }\end{array}$ & \multicolumn{5}{|c|}{ Natural resources are abundant ${ }^{1}$; Rich in natural water resources ${ }^{2}$; There are many sources of food ${ }^{3}$} \\
\hline & Climate Disasters & \multicolumn{5}{|c|}{$\begin{array}{l}\text { Disastrous weather was less before the Ming Dynasty, but increased after the Ming Dynasty; Vulnerable } \\
\text { to floods and droughts }{ }^{4} \text {; Suffers from typhoon damage }{ }^{5}\end{array}$} \\
\hline \multirow{3}{*}{$\begin{array}{l}\text { Direct } \\
\text { Description }\end{array}$} & $\begin{array}{l}\text { Width of Yudai } \\
\text { Trench }\end{array}$ & $\begin{array}{l}\text { Culvert; } \\
\text { Disappearance }\end{array}$ & $\begin{array}{l}6 \mathrm{~m} \text { ( } 2 \text { Zhang) } \\
\text { wide; Sewage } \\
\text { surges to the } \\
\text { ground }{ }^{7} ; \\
\text { Deposition; Water } \\
\text { without a source } \\
8 ; \text { The trenches } \\
\text { had no one to } \\
\text { manage and clean } \\
\text { up the dredging } 9\end{array}$ & $\begin{array}{l}\text { Merchants filled } \\
\text { in the water to } \\
\text { make land }{ }^{10} ; \\
\text { Cross the river } \\
\text { with a bridge }{ }^{11} \text {; } \\
\text { Less than } 15 \text { m (5 } \\
\text { Zhang); Silt }\end{array}$ & $\begin{array}{l}\text { Trench outlet } \\
\text { blockage; It can } \\
\text { only } \\
\text { accommodate } \\
\text { two boats }^{13}\end{array}$ & $\begin{array}{l}\text { Trench can } \\
\text { withstand } \\
\text { typhoon; The } \\
\text { trench is } 4800 \mathrm{~m} \\
\text { (160 Zhang) long, } \\
63 \mathrm{~m} \text { (20 Zhang) } \\
\text { wide, and } 9 \mathrm{~m} \mathrm{(3} \\
\text { Zhang) deep; } \\
\text { Large ships can } \\
\text { pass through }\end{array}$ \\
\hline & Area of West Lake & $\begin{array}{l}\text { Broken stones } \\
\text { and the remains } \\
\text { of the lake }{ }^{6}\end{array}$ & Pond & $\begin{array}{l}\text { Not as broad as in } \\
\text { the Song and } \\
\text { Yuan Dynasties }{ }^{12} \text {; } \\
\text { Lake silting in the } \\
\text { throat; Artificially } \\
\text { filled lake }\end{array}$ & $\begin{array}{l}\text { White water } \\
\text { rafting }{ }^{14} \text {; West } \\
\text { Lake shrank in } \\
\text { area; The west } \\
\text { side silted up, } \\
\text { leaving only the } \\
\text { east side }\end{array}$ & $\begin{array}{c}450 \mathrm{~m} \text { (150 } \\
\text { Zhang) long; } \\
\text { More than } 1550 \mathrm{~m} \\
\text { (500 Zhang) in } \\
\text { width; White } \\
\text { water rafting }\end{array}$ \\
\hline & $\begin{array}{l}\text { Volume of } \\
\text { Nanhao Trench }\end{array}$ & $\begin{array}{l}\text { Big flood; } \\
\text { Culvert }\end{array}$ & $\begin{array}{l}\text { Easy to strand; } 2 \\
\text { m wide; Loss of } \\
\text { shipping benefits; } \\
\text { Silt; Only } 300 \text { m }\end{array}$ & $\begin{array}{l}\text { Dredge; Trench } \\
\text { reopened to ships }\end{array}$ & $\begin{array}{l}\text { Shipping is busy; } \\
\text { Trench is large } \\
\text { enough for ships } \\
\text { to sail in }\end{array}$ & $\begin{array}{l}\text { The river is } 30 \mathrm{~m} \\
\text { (10 Zhang) wide } \\
\text { and is called the } \\
\text { little sea; No } \\
\text { storm fear, and } \\
\text { prepare for fire }{ }^{15} \text {; } \\
\text { Socioeconomic } \\
\text { center }\end{array}$ \\
\hline
\end{tabular}

Chinese translations: ${ }^{1}$ 多犀、象、玳琩、珠玑、银、铜、果、布之凑 $/$ 膏腆之地 ${ }^{2}{ }^{2}$ 有水沉陵 $/$ 天然水道/井泉众多; ${ }^{3}$ 水使民得甘食; ${ }^{4}$ 易遇水 害和干旱; ${ }^{5}$ 常苦揕风/濒海巨浸; ${ }^{6}$ 败石残湖 $;{ }^{7}$ 潦水反喷, 秽水上侵; ${ }^{8}$ 无源之水; ${ }^{9}$ 无人管理与清污疏浚; ${ }^{10}$ 豪绅争地, 使濠身日狭; ${ }^{11}$ 飞桥 跨水; 12 不如宋元之广; 13 拓城填壕，止容二艇; 14 泛舟/竞渡其间; 15 无风涛恐，且备火灾

Table A3. Semantic difference analysis for the historical records of economic systems.

\begin{tabular}{|c|c|c|c|c|c|c|}
\hline \multicolumn{2}{|c|}{ Emotional Intensity } & 1 & 2 & 3 & 4 & 5 \\
\hline \multicolumn{2}{|c|}{ Overviews } & Extreme Poor & Poor & Medium & Good & Extreme Good \\
\hline \multirow[t]{2}{*}{$\begin{array}{c}\text { Contextual } \\
\text { Description of } \\
\text { Economic System }\end{array}$} & Commercial scale & $\begin{array}{l}\text { Destruction in the } \\
\text { Yuan Dynasty led to } \\
\text { a decline in trade }\end{array}$ & $\begin{array}{l}\text { Disappearance of } \\
\text { commercial value }\end{array}$ & $\begin{array}{c}\text { Not as prosperous } \\
\text { as in the Song and } \\
\text { Yuan }\end{array}$ & ------- & $\begin{array}{l}\text { The people, the } \\
\text { ships, the rich } \\
\text { merchants, the } \\
\text { precious goods } \\
\text { were all gathered } \\
\text { here }{ }^{1} \text {; It was } \\
\text { several times more } \\
\text { prosperous than } \\
\text { Qinhuai River } \\
\text { commercial center }{ }^{2} \text {; } \\
\text { Commercial shops } \\
\text { and art studios are } \\
\text { everywhere }\end{array}$ \\
\hline & Import and export & $\begin{array}{r}\text { Guangzhou's total i } \\
\text { accounts for }\end{array}$ & $\begin{array}{l}\text { ort and export volu } \\
\% \text { of the national re }\end{array}$ & $\begin{array}{l}\text { ncreased by } 80 \% \text {; Th } \\
\text { e; There are many ti }\end{array}$ & $\begin{array}{l}\text { ade's revenue is as h } \\
s \text { more precious good }\end{array}$ & $\begin{array}{l}\text { as } 2 \text { million, which } \\
\text { han before }\end{array}$ \\
\hline
\end{tabular}


Table A3. Cont.

\begin{tabular}{|c|c|c|c|c|c|c|}
\hline \multicolumn{2}{|c|}{ Emotional Intensity } & 1 & 2 & 3 & 4 & 5 \\
\hline \multicolumn{2}{|c|}{ Overviews } & Extreme Poor & Poor & Medium & Good & Extreme Good \\
\hline \multirow[t]{2}{*}{ Direct Description } & $\begin{array}{l}\text { Number of Shops in } \\
\text { Gaodi Street }\end{array}$ & $\begin{array}{l}\text { Commercial shops } \\
\text { have been largely } \\
\text { demolished }\end{array}$ & $\begin{array}{l}\text { The number of } \\
\text { shops has decreased }\end{array}$ & $\begin{array}{l}\text { The decline in } \\
\text { Gaodi Street } \\
\text { commerce; } \\
\text { changing from } \\
\text { flourishing to } \\
\text { decadence }\end{array}$ & $\begin{array}{l}\text { Gaodi Street } \\
\text { gradually } \\
\text { developed }\end{array}$ & Business core area \\
\hline & Salt Storage & ------- & $\begin{array}{l}\text { Got into trouble and } \\
\text { went bankrupt }\end{array}$ & ------- & $\begin{array}{l}\text { A place that } \\
\text { produces salt }\end{array}$ & $\begin{array}{l}\text { The salt industry is } \\
\text { large and profitable; } \\
\text { Treasured place }\end{array}$ \\
\hline & $\begin{array}{l}\text { Quantity Produced } \\
\text { and Sold of } \\
\text { Cantonese Style } \\
\text { Furniture }\end{array}$ & $\begin{array}{c}\text { The furniture } \\
\text { industry went } \\
\text { bankrupt }\end{array}$ & ------- & $\begin{array}{l}\text { Court techniques } \\
\text { laid the foundation }\end{array}$ & ------- & $\begin{array}{l}\text { There are rows and } \\
\text { rows of workshops, } \\
\text { and the market } \\
\text { stretches for ten } \\
\text { miles }{ }^{6} \text {; The sources } \\
\text { of wood raw } \\
\text { materials are } \\
\text { extensive; One of } \\
\text { the three most } \\
\text { famous furniture of } \\
\text { the Qing Dynasty; } \\
\text { Unique status }\end{array}$ \\
\hline & $\begin{array}{l}\text { Quantity Produced } \\
\text { and Sold of Musical } \\
\text { Instruments }\end{array}$ & $\begin{array}{l}\text { Went bankrupt and } \\
\text { disappeared }\end{array}$ & $\begin{array}{c}\text { On the wane; } \\
\text { Musical } \\
\text { instruments are one } \\
\text { of the commodities } \\
\text { exported }\end{array}$ & ------- & ------- & $\begin{array}{l}\text { Sells in distant } \\
\text { markets overseas; } \\
\text { The largest } \\
\text { professional } \\
\text { musical instrument } \\
\text { production and } \\
\text { sales street; The } \\
\text { peak of the musical } \\
\text { instrument industry }\end{array}$ \\
\hline
\end{tabular}

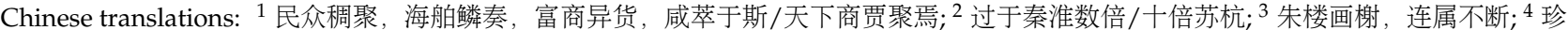
货之盛亦倍于前; ${ }^{5}$ 宝地/枢纽/中心/集散地; 6 作坊鳞次栉比, 行市绵延十里.

Table A4. Semantic difference analysis for the historical records of cultural systems.

\begin{tabular}{|c|c|c|c|c|c|c|}
\hline \multicolumn{2}{|c|}{ Emotional Intensity } & 1 & 2 & 3 & 4 & 5 \\
\hline \multicolumn{2}{|c|}{ Overviews } & Extreme Poor & Poor & Medium & Good & Extreme Good \\
\hline $\begin{array}{c}\text { Contextual } \\
\text { Description of } \\
\text { Cultural System }\end{array}$ & $\begin{array}{l}\text { The Construction } \\
\text { Scale of the } \\
\text { Nanyuan Garden }\end{array}$ & $\begin{array}{c}\text { Suffered } \\
\text { destruction; } \\
\text { Nanyuan Garden is } \\
\text { destroyed and no } \\
\text { longer exists }\end{array}$ & $\begin{array}{l}\text { The literati were } \\
\text { mentally wounded; } \\
\text { Rebuild; Lingnan } \\
\text { literature was not } \\
\text { valued }\end{array}$ & $\begin{array}{l}\text { Rebuild the } \\
\text { Nanyuan Garden }{ }^{1} \text {; } \\
\text { old site; Become an } \\
\text { office }\end{array}$ & $\begin{array}{l}\text { Creation of poetry } \\
\text { club; Ancestral hall } \\
\text { was built in the } \\
\text { Nanyuan Garden; } \\
\text { Establish Guangya } \\
\text { Book Concern }\end{array}$ & $\begin{array}{l}\text { Literature seminars } \\
\text { are held frequently } \\
\text { in Nanyuan } \\
\text { Garden }^{2}\end{array}$ \\
\hline \multirow[t]{2}{*}{ Direct Description } & $\begin{array}{l}\text { The Innovation } \\
\text { Level of } \\
\text { Cantonese-Style } \\
\text { Furniture }\end{array}$ & $\begin{array}{c}\text { The furniture } \\
\text { industry went } \\
\text { bankrupt }\end{array}$ & ------- & $\begin{array}{l}\text { Court techniques } \\
\text { laid the foundation }\end{array}$ & ------- & $\begin{array}{l}\text { Wood furniture is } \\
\text { divided into } \\
\text { different workshops } \\
\text { according to } \\
\text { different processes; } \\
\text { Furniture combines } \\
\text { ancient and modern } \\
\text { essence, fusion of } \\
\text { Chinese and foreign } \\
\text { characteristics to } \\
\text { form a unique } \\
\text { style }^{3}\end{array}$ \\
\hline & $\begin{array}{l}\text { The Innovation } \\
\text { Level of Musical } \\
\text { Instrument }\end{array}$ & $\begin{array}{l}\text { Went bankrupt and } \\
\text { disappeared }\end{array}$ & $\begin{array}{c}\text { On the wane; } \\
\text { Musical } \\
\text { instruments are one } \\
\text { of the commodities } \\
\text { exported }\end{array}$ & ------- & ------- & $\begin{array}{l}\text { On the moon night, } \\
\text { the music of } \\
\text { musical instruments } \\
\text { could be heard by } \\
\text { the trench bank } \\
\text { Musical } \\
\text { instruments have } \\
\text { unique artistic } \\
\text { characteristics }\end{array}$ \\
\hline
\end{tabular}

Chinese translations: ${ }^{1}$ 重整废园/复修南园/修复抗风轩; ${ }^{2}$ 举办诗钟之会; ${ }^{3}$ 融古今、纳中外, 形成独特风格/中西融合, 崇尚自然情态, 以 曲为美; ${ }^{4}$ 月夜满江闻管弦. 


\section{Appendix C}

(I) Simulated temperature changes over eastern China over the past 1000 years, with a temporal resolution of 10 years; (II) Temperature curves of eastern and central China over the past 2000 years derived from historical documents, with a 30 year temporal resolution; (III) Tree-ring-derived temperature variations in the central Qilian Mountains over the past 1000 years, with a temporal resolution of 3 years; (IV) Integrated temperature series over the past 2000 years from the Dunde, Gurria, Dassoppe and Progonge ice cores with a time resolution of 10 years; $(\mathrm{V})$ Temperature series over the past millennium reconstructed from ice cores, stalagmites, tree rings, peat, lake sediments, palynology and historical data, with a time resolution of 10 years; (VI) China's temperature curves over the past 2000 years reconstructed by integrating ice cores, tree rings, lake deposits and historical data, with a temporal resolution of 10 years; (VII) Temperature changes over the past 2000 years as indicated by the development of paleosol (black spot) and glacier (black triangle), with no fixed temporal resolution; The smooth solid line represents the centennial scale temperature change, and the dashed line represents the average of each series.

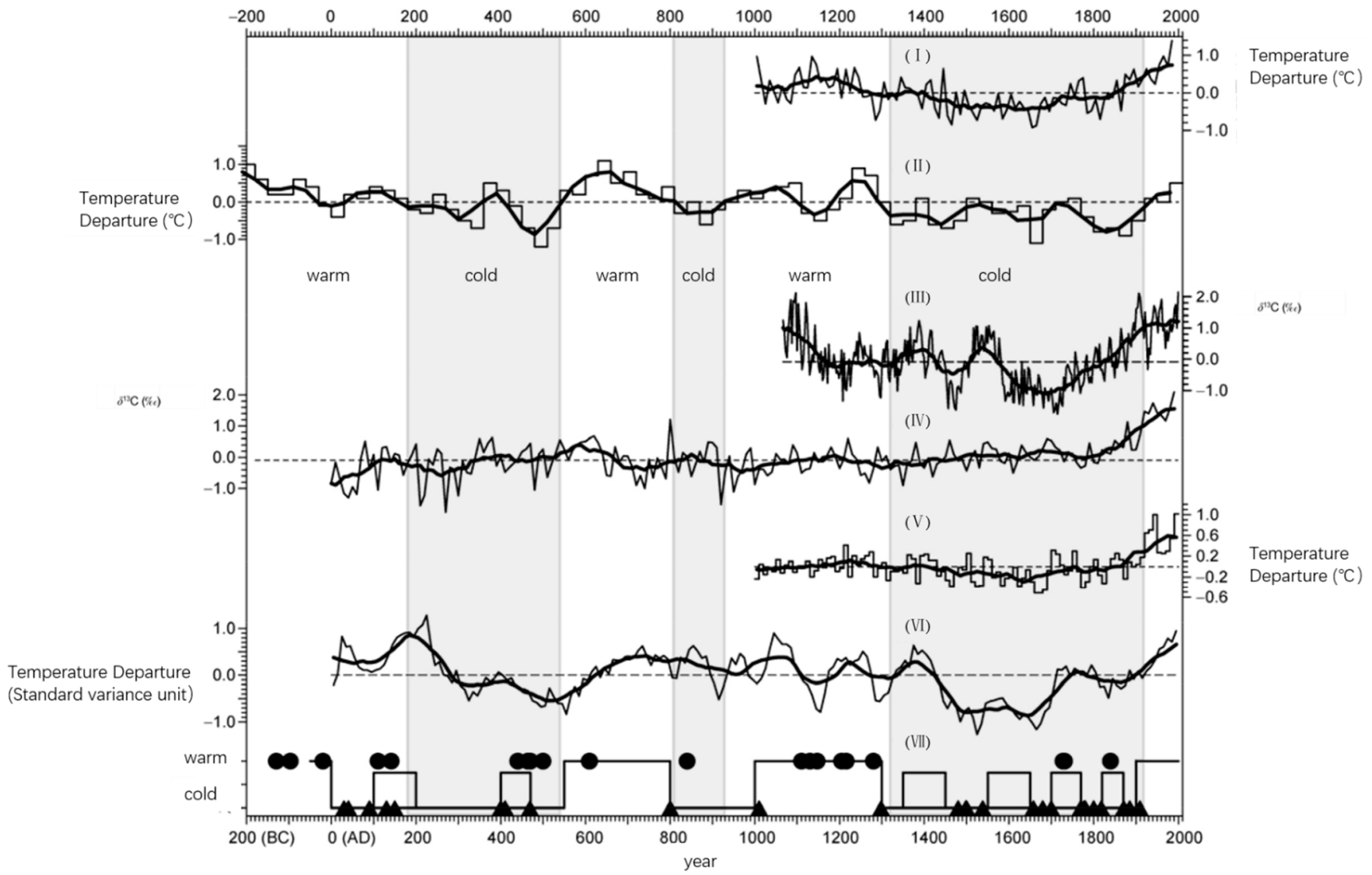

Figure A1. Reconstructed and simulated sequences of temperature changes in China during the past 1000 2000 years [57].

In this paper, the temperature departure data provided by $(\mathrm{V})$ were selected as representative of climate change [57]. 
Table A5. Correlation analysis of temperature change and natural system change.

\begin{tabular}{|c|c|c|c|c|c|}
\hline Year & $\begin{array}{l}\text { Temperature } \\
\left(\mathrm{x} /{ }^{\circ} \mathrm{C}\right)\end{array}$ & $\begin{array}{c}\text { Width of Yudai } \\
\text { Trench }\end{array}$ & Area of West Lake & $\begin{array}{c}\text { Volume of Nanhao } \\
\text { Trench }\end{array}$ & $\begin{array}{c}\text { Natural System Mean } \\
\left(\mathrm{y}_{1}\right)\end{array}$ \\
\hline 1000 & 0.40 & 5.00 & 4.00 & 4.00 & 4.33 \\
\hline 1010 & 0.35 & 5.00 & 4.00 & 4.00 & 4.33 \\
\hline 1020 & 0.25 & 5.00 & 4.00 & 4.00 & 4.33 \\
\hline 1030 & 0.20 & 5.00 & 4.00 & 4.00 & 4.33 \\
\hline 1040 & 0.10 & 5.00 & 4.00 & 4.00 & 4.33 \\
\hline 1050 & 0.08 & 5.00 & 4.00 & 4.00 & 4.33 \\
\hline 1060 & 0.05 & 5.00 & 4.00 & 4.00 & 4.33 \\
\hline 1070 & 0.02 & 5.00 & 4.00 & 4.00 & 4.33 \\
\hline 1080 & 0.00 & 5.00 & 4.00 & 4.00 & 4.33 \\
\hline 1090 & -0.05 & 5.00 & 4.00 & 4.00 & 4.33 \\
\hline 1100 & -0.15 & 5.00 & 4.00 & 4.00 & 4.33 \\
\hline 1110 & -1.45 & 5.00 & 4.00 & 4.00 & 4.33 \\
\hline 1120 & -1.60 & 5.00 & 4.00 & 4.00 & 4.33 \\
\hline 1130 & -1.75 & 5.00 & 4.00 & 4.00 & 4.33 \\
\hline 1140 & -1.80 & 5.00 & 4.00 & 4.00 & 4.33 \\
\hline 1150 & -1.85 & 5.00 & 4.00 & 4.00 & 4.33 \\
\hline 1160 & -1.80 & 5.00 & 4.00 & 4.00 & 4.33 \\
\hline 1170 & -1.75 & 5.00 & 4.00 & 4.00 & 4.33 \\
\hline 1180 & -1.70 & 5.00 & 4.00 & 4.00 & 4.33 \\
\hline 1190 & -1.50 & 5.00 & 4.00 & 4.00 & 4.33 \\
\hline 1200 & -0.40 & 5.00 & 4.00 & 4.00 & 4.33 \\
\hline 1210 & -0.30 & 5.00 & 4.00 & 5.00 & 4.67 \\
\hline 1220 & -0.25 & 5.00 & 4.00 & 5.00 & 4.67 \\
\hline 1230 & -0.30 & 5.00 & 4.00 & 5.00 & 4.67 \\
\hline 1240 & -0.75 & 5.00 & 4.00 & 5.00 & 4.67 \\
\hline 1250 & -1.25 & 5.00 & 4.00 & 5.00 & 4.67 \\
\hline 1260 & -1.75 & 5.00 & 4.00 & 5.00 & 4.67 \\
\hline 1270 & -1.85 & 4.00 & 4.00 & 5.00 & 4.33 \\
\hline 1280 & -1.80 & 4.00 & 4.00 & 5.00 & 4.33 \\
\hline 1290 & -1.50 & 4.00 & 4.00 & 5.00 & 4.33 \\
\hline 1300 & -1.00 & 4.00 & 4.00 & 5.00 & 4.33 \\
\hline 1310 & -1.10 & 4.00 & 4.00 & 5.00 & 4.33 \\
\hline 1320 & -1.80 & 4.00 & 4.00 & 5.00 & 4.33 \\
\hline 1330 & -1.75 & 4.00 & 4.00 & 5.00 & 4.33 \\
\hline 1340 & -1.60 & 4.00 & 4.00 & 5.00 & 4.33 \\
\hline 1350 & -1.50 & 4.00 & 4.00 & 5.00 & 4.33 \\
\hline 1360 & -1.25 & 4.00 & 4.00 & 2.00 & 3.33 \\
\hline 1370 & -1.15 & 4.00 & 4.00 & 2.00 & 3.33 \\
\hline 1380 & -1.00 & 4.00 & 4.00 & 2.00 & 3.33 \\
\hline 1390 & -0.80 & 4.00 & 4.00 & 2.00 & 3.33 \\
\hline 1400 & -0.90 & 4.00 & 4.00 & 2.00 & 3.33 \\
\hline 1410 & -1.00 & 4.00 & 4.00 & 2.00 & 3.33 \\
\hline 1420 & -1.10 & 4.00 & 4.00 & 2.00 & 3.33 \\
\hline 1430 & -1.20 & 4.00 & 3.00 & 2.00 & 3.00 \\
\hline 1440 & -1.25 & 4.00 & 3.00 & 2.00 & 3.00 \\
\hline 1450 & -1.30 & 4.00 & 3.00 & 2.00 & 3.00 \\
\hline 1460 & -1.35 & 4.00 & 3.00 & 2.00 & 3.00 \\
\hline 1470 & -1.40 & 4.00 & 3.00 & 2.00 & 3.00 \\
\hline 1480 & -1.45 & 4.00 & 3.00 & 2.00 & 3.00 \\
\hline 1490 & -1.50 & 4.00 & 3.00 & 2.00 & 3.00 \\
\hline 1500 & -1.45 & 4.00 & 3.00 & 2.00 & 3.00 \\
\hline 1510 & -1.40 & 4.00 & 3.00 & 2.00 & 3.00 \\
\hline 1520 & -1.30 & 4.00 & 3.00 & 2.00 & 3.00 \\
\hline 1530 & -1.25 & 4.00 & 3.00 & 2.00 & 3.00 \\
\hline
\end{tabular}


Table A5. Cont.

\begin{tabular}{|c|c|c|c|c|c|}
\hline Year & $\begin{array}{c}\text { Temperature } \\
\left(\mathrm{x} /{ }^{\circ} \mathrm{C}\right)\end{array}$ & $\begin{array}{c}\text { Width of Yudai } \\
\text { Trench }\end{array}$ & Area of West Lake & $\begin{array}{c}\text { Volume of Nanhao } \\
\text { Trench }\end{array}$ & $\begin{array}{c}\text { Natural System Mean } \\
\left(\mathrm{y}_{1}\right)\end{array}$ \\
\hline 1540 & -1.20 & 4.00 & 3.00 & 2.00 & 3.00 \\
\hline 1550 & -1.15 & 4.00 & 3.00 & 2.00 & 3.00 \\
\hline 1560 & -1.10 & 3.00 & 3.00 & 2.00 & 2.67 \\
\hline 1570 & -1.15 & 3.00 & 3.00 & 2.00 & 2.67 \\
\hline 1580 & -1.20 & 3.00 & 3.00 & 2.00 & 2.67 \\
\hline 1590 & -1.25 & 3.00 & 3.00 & 2.00 & 2.67 \\
\hline 1600 & -1.35 & 3.00 & 3.00 & 2.00 & 2.67 \\
\hline 1610 & -1.50 & 3.00 & 3.00 & 2.00 & 2.67 \\
\hline 1620 & -1.60 & 3.00 & 3.00 & 2.00 & 2.67 \\
\hline 1630 & -1.70 & 3.00 & 3.00 & 2.00 & 2.67 \\
\hline 1640 & -1.75 & 3.00 & 3.00 & 2.00 & 2.67 \\
\hline 1650 & -1.85 & 3.00 & 2.00 & 2.00 & 2.33 \\
\hline 1660 & -1.75 & 3.00 & 2.00 & 2.00 & 2.33 \\
\hline 1670 & -1.70 & 3.00 & 2.00 & 2.00 & 2.33 \\
\hline 1680 & -1.65 & 3.00 & 2.00 & 2.00 & 2.33 \\
\hline 1690 & -1.60 & 3.00 & 2.00 & 2.00 & 2.33 \\
\hline 1700 & -1.55 & 3.00 & 2.00 & 2.00 & 2.33 \\
\hline 1710 & -1.50 & 3.00 & 2.00 & 3.00 & 2.67 \\
\hline 1720 & -1.40 & 3.00 & 2.00 & 3.00 & 2.67 \\
\hline 1730 & -1.30 & 3.00 & 2.00 & 3.00 & 2.67 \\
\hline 1740 & -1.20 & 3.00 & 2.00 & 3.00 & 2.67 \\
\hline 1750 & -1.10 & 3.00 & 2.00 & 3.00 & 2.67 \\
\hline 1760 & -0.95 & 3.00 & 2.00 & 3.00 & 2.67 \\
\hline 1770 & -0.80 & 3.00 & 2.00 & 3.00 & 2.67 \\
\hline 1780 & -0.65 & 3.00 & 2.00 & 3.00 & 2.67 \\
\hline 1790 & -0.60 & 3.00 & 2.00 & 3.00 & 2.67 \\
\hline 1800 & -0.50 & 3.00 & 2.00 & 3.00 & 2.67 \\
\hline 1810 & -0.45 & 3.00 & 2.00 & 3.00 & 2.67 \\
\hline 1820 & -0.50 & 3.00 & 2.00 & 3.00 & 2.67 \\
\hline 1830 & -0.75 & 3.00 & 2.00 & 2.00 & 2.33 \\
\hline 1840 & -1.00 & 3.00 & 2.00 & 2.00 & 2.33 \\
\hline 1850 & -1.30 & 3.00 & 2.00 & 2.00 & 2.33 \\
\hline 1860 & -1.40 & 3.00 & 2.00 & 2.00 & 2.33 \\
\hline 1870 & -1.35 & 3.00 & 2.00 & 2.00 & 2.33 \\
\hline 1880 & -1.25 & 3.00 & 2.00 & 2.00 & 2.33 \\
\hline 1890 & -0.75 & 3.00 & 2.00 & 2.00 & 2.33 \\
\hline 1900 & 0.00 & 3.00 & 2.00 & 2.00 & 2.33 \\
\hline 1910 & 0.05 & 3.00 & 2.00 & 2.00 & 2.33 \\
\hline 1920 & 0.00 & 2.00 & 1.00 & 1.00 & 1.33 \\
\hline 1930 & -0.10 & 2.00 & 1.00 & 1.00 & 1.33 \\
\hline 1940 & -0.20 & 1.00 & 1.00 & 1.00 & 1.00 \\
\hline 1950 & 0.00 & 1.00 & 1.00 & 1.00 & 1.00 \\
\hline 1960 & 0.25 & 1.00 & 1.00 & 1.00 & 1.00 \\
\hline 1970 & 0.40 & 1.00 & 1.00 & 1.00 & 1.00 \\
\hline 1980 & 0.55 & 1.00 & 1.00 & 1.00 & 1.00 \\
\hline 1990 & 0.70 & 1.00 & 1.00 & 1.00 & 1.00 \\
\hline 2000 & 0.85 & 1.00 & 1.00 & 1.00 & 1.00 \\
\hline
\end{tabular}


Table A6. Correlation analysis of temperature change and economic system change.

\begin{tabular}{|c|c|c|c|c|c|c|c|}
\hline Year & $\begin{array}{c}\text { Temperature } \\
\left(\mathrm{x} /{ }^{\circ} \mathrm{C}\right)\end{array}$ & $\begin{array}{c}\text { Scale of Yudai } \\
\text { Trench } \\
\text { Commerce }\end{array}$ & $\begin{array}{l}\text { Number of } \\
\text { Shops in } \\
\text { Gaodi Street }\end{array}$ & Salt Storage & $\begin{array}{c}\text { Quantity } \\
\text { Produced and } \\
\text { Sold of } \\
\text { Cantonese Style } \\
\text { Furniture }\end{array}$ & $\begin{array}{c}\text { Quantity } \\
\text { Produced and } \\
\text { Sold of Musical } \\
\text { Instruments }\end{array}$ & $\begin{array}{c}\text { Economic } \\
\text { System Mean } \\
\left(\mathrm{y}_{2}\right)\end{array}$ \\
\hline 1000 & 0.40 & 2.00 & 4.00 & 4.00 & 3.00 & 2.00 & 3.00 \\
\hline 1010 & 0.35 & 5.00 & 4.00 & 4.00 & 3.00 & 2.00 & 3.60 \\
\hline 1020 & 0.25 & 5.00 & 4.00 & 4.00 & 3.00 & 2.00 & 3.60 \\
\hline 1030 & 0.20 & 5.00 & 4.00 & 4.00 & 3.00 & 2.00 & 3.60 \\
\hline 1040 & 0.10 & 5.00 & 4.00 & 4.00 & 3.00 & 2.00 & 3.60 \\
\hline 1050 & 0.08 & 5.00 & 4.00 & 4.00 & 3.00 & 2.00 & 3.60 \\
\hline 1060 & 0.05 & 5.00 & 4.00 & 4.00 & 3.00 & 2.00 & 3.60 \\
\hline 1070 & 0.02 & 5.00 & 4.00 & 4.00 & 3.00 & 2.00 & 3.60 \\
\hline 1080 & 0.00 & 5.00 & 4.00 & 4.00 & 3.00 & 2.00 & 3.60 \\
\hline 1090 & -0.05 & 5.00 & 4.00 & 4.00 & 3.00 & 2.00 & 3.60 \\
\hline 1100 & -0.15 & 5.00 & 4.00 & 4.00 & 3.00 & 2.00 & 3.60 \\
\hline 1110 & -1.45 & 5.00 & 4.00 & 4.00 & 3.00 & 2.00 & 3.60 \\
\hline 1120 & -1.60 & 5.00 & 4.00 & 4.00 & 3.00 & 2.00 & 3.60 \\
\hline 1130 & -1.75 & 5.00 & 4.00 & 4.00 & 3.00 & 2.00 & 3.60 \\
\hline 1140 & -1.80 & 5.00 & 4.00 & 4.00 & 3.00 & 2.00 & 3.60 \\
\hline 1150 & -1.85 & 5.00 & 4.00 & 4.00 & 3.00 & 2.00 & 3.60 \\
\hline 1160 & -1.80 & 5.00 & 4.00 & 4.00 & 3.00 & 2.00 & 3.60 \\
\hline 1170 & -1.75 & 5.00 & 4.00 & 4.00 & 3.00 & 2.00 & 3.60 \\
\hline 1180 & -1.70 & 5.00 & 4.00 & 4.00 & 3.00 & 2.00 & 3.60 \\
\hline 1190 & -1.50 & 5.00 & 4.00 & 4.00 & 3.00 & 2.00 & 3.60 \\
\hline 1200 & -0.40 & 5.00 & 4.00 & 4.00 & 3.00 & 2.00 & 3.60 \\
\hline 1210 & -0.30 & 5.00 & 4.00 & 4.00 & 3.00 & 2.00 & 3.60 \\
\hline 1220 & -0.25 & 5.00 & 4.00 & 4.00 & 3.00 & 2.00 & 3.60 \\
\hline 1230 & -0.30 & 5.00 & 4.00 & 4.00 & 3.00 & 2.00 & 3.60 \\
\hline 1240 & -0.75 & 5.00 & 4.00 & 4.00 & 3.00 & 2.00 & 3.60 \\
\hline 1250 & -1.25 & 5.00 & 4.00 & 4.00 & 3.00 & 2.00 & 3.60 \\
\hline 1260 & -1.75 & 5.00 & 4.00 & 4.00 & 3.00 & 2.00 & 3.60 \\
\hline 1270 & -1.85 & 2.00 & 3.00 & 4.00 & 3.00 & 3.00 & 3.00 \\
\hline 1280 & -1.80 & 2.00 & 3.00 & 4.00 & 3.00 & 3.00 & 3.00 \\
\hline 1290 & -1.50 & 2.00 & 3.00 & 4.00 & 3.00 & 3.00 & 3.00 \\
\hline 1300 & -1.00 & 2.00 & 3.00 & 4.00 & 3.00 & 3.00 & 3.00 \\
\hline 1310 & -1.10 & 2.00 & 3.00 & 4.00 & 3.00 & 3.00 & 3.00 \\
\hline 1320 & -1.80 & 2.00 & 3.00 & 4.00 & 3.00 & 3.00 & 3.00 \\
\hline 1330 & -1.75 & 2.00 & 3.00 & 4.00 & 3.00 & 3.00 & 3.00 \\
\hline 1340 & -1.60 & 2.00 & 3.00 & 4.00 & 3.00 & 3.00 & 3.00 \\
\hline 1350 & -1.50 & 2.00 & 3.00 & 4.00 & 3.00 & 3.00 & 3.00 \\
\hline 1360 & -1.25 & 2.00 & 3.00 & 4.00 & 3.00 & 3.00 & 3.00 \\
\hline 1370 & -1.15 & 2.00 & 3.00 & 4.00 & 3.00 & 3.00 & 3.00 \\
\hline 1380 & -1.00 & 2.00 & 3.00 & 4.00 & 3.00 & 3.00 & 3.00 \\
\hline 1390 & -0.80 & 5.00 & 3.00 & 4.00 & 5.00 & 5.00 & 4.40 \\
\hline 1400 & -0.90 & 5.00 & 3.00 & 4.00 & 5.00 & 5.00 & 4.40 \\
\hline 1410 & -1.00 & 5.00 & 3.00 & 4.00 & 5.00 & 5.00 & 4.40 \\
\hline 1420 & -1.10 & 5.00 & 3.00 & 4.00 & 5.00 & 5.00 & 4.40 \\
\hline 1430 & -1.20 & 5.00 & 3.00 & 4.00 & 5.00 & 5.00 & 4.40 \\
\hline 1440 & -1.25 & 5.00 & 3.00 & 4.00 & 5.00 & 5.00 & 4.40 \\
\hline 1450 & -1.30 & 5.00 & 3.00 & 4.00 & 5.00 & 5.00 & 4.40 \\
\hline 1460 & -1.35 & 5.00 & 3.00 & 4.00 & 5.00 & 5.00 & 4.40 \\
\hline 1470 & -1.40 & 5.00 & 3.00 & 4.00 & 5.00 & 5.00 & 4.40 \\
\hline 1480 & -1.45 & 5.00 & 3.00 & 4.00 & 5.00 & 5.00 & 4.40 \\
\hline 1490 & -1.50 & 5.00 & 3.00 & 4.00 & 5.00 & 5.00 & 4.40 \\
\hline 1500 & -1.45 & 5.00 & 3.00 & 4.00 & 5.00 & 5.00 & 4.40 \\
\hline 1510 & -1.40 & 5.00 & 3.00 & 4.00 & 5.00 & 5.00 & 4.40 \\
\hline 1520 & -1.30 & 5.00 & 3.00 & 4.00 & 5.00 & 5.00 & 4.40 \\
\hline 1530 & -1.25 & 5.00 & 3.00 & 4.00 & 5.00 & 5.00 & 4.40 \\
\hline 1540 & -1.20 & 5.00 & 3.00 & 4.00 & 5.00 & 5.00 & 4.40 \\
\hline 1550 & -1.15 & 5.00 & 3.00 & 4.00 & 5.00 & 5.00 & 4.40 \\
\hline 1560 & -1.10 & 5.00 & 3.00 & 4.00 & 5.00 & 5.00 & 4.40 \\
\hline 1570 & -1.15 & 5.00 & 3.00 & 4.00 & 5.00 & 5.00 & 4.40 \\
\hline 1580 & -1.20 & 5.00 & 3.00 & 4.00 & 5.00 & 5.00 & 4.40 \\
\hline
\end{tabular}


Table A6. Cont.

\begin{tabular}{|c|c|c|c|c|c|c|c|}
\hline Year & $\begin{array}{l}\text { Temperature } \\
\left(\mathbf{x} /{ }^{\circ} \mathrm{C}\right)\end{array}$ & $\begin{array}{c}\text { Scale of Yudai } \\
\text { Trench } \\
\text { Commerce }\end{array}$ & $\begin{array}{l}\text { Number of } \\
\text { Shops in } \\
\text { Gaodi Street }\end{array}$ & Salt Storage & $\begin{array}{c}\text { Quantity } \\
\text { Produced and } \\
\text { Sold of } \\
\text { Cantonese Style } \\
\text { Furniture }\end{array}$ & $\begin{array}{c}\text { Quantity } \\
\text { Produced and } \\
\text { Sold of Musical } \\
\text { Instruments }\end{array}$ & $\begin{array}{c}\text { Economic } \\
\text { System Mean } \\
\left(\mathrm{y}_{2}\right)\end{array}$ \\
\hline 1590 & -1.25 & 5.00 & 3.00 & 4.00 & 5.00 & 5.00 & 4.40 \\
\hline 1600 & -1.35 & 5.00 & 3.00 & 4.00 & 3.00 & 3.00 & 3.60 \\
\hline 1610 & -1.50 & 5.00 & 3.00 & 4.00 & 3.00 & 3.00 & 3.60 \\
\hline 1620 & -1.60 & 5.00 & 3.00 & 4.00 & 3.00 & 3.00 & 3.60 \\
\hline 1630 & -1.70 & 5.00 & 3.00 & 4.00 & 3.00 & 3.00 & 3.60 \\
\hline 1640 & -1.75 & 5.00 & 3.00 & 4.00 & 3.00 & 3.00 & 3.60 \\
\hline 1650 & -1.85 & 5.00 & 5.00 & 5.00 & 5.00 & 5.00 & 5.00 \\
\hline 1660 & -1.75 & 5.00 & 5.00 & 5.00 & 5.00 & 5.00 & 5.00 \\
\hline 1670 & -1.70 & 5.00 & 5.00 & 5.00 & 5.00 & 5.00 & 5.00 \\
\hline 1680 & -1.65 & 5.00 & 5.00 & 5.00 & 5.00 & 5.00 & 5.00 \\
\hline 1690 & -1.60 & 5.00 & 5.00 & 5.00 & 5.00 & 5.00 & 5.00 \\
\hline 1700 & -1.55 & 5.00 & 5.00 & 5.00 & 5.00 & 5.00 & 5.00 \\
\hline 1710 & -1.50 & 5.00 & 5.00 & 5.00 & 5.00 & 5.00 & 5.00 \\
\hline 1720 & -1.40 & 5.00 & 5.00 & 5.00 & 5.00 & 5.00 & 5.00 \\
\hline 1730 & -1.30 & 5.00 & 5.00 & 5.00 & 5.00 & 5.00 & 5.00 \\
\hline 1740 & -1.20 & 5.00 & 3.00 & 5.00 & 5.00 & 5.00 & 4.60 \\
\hline 1750 & -1.10 & 5.00 & 3.00 & 5.00 & 5.00 & 5.00 & 4.60 \\
\hline 1760 & -0.95 & 5.00 & 3.00 & 5.00 & 5.00 & 5.00 & 4.60 \\
\hline 1770 & -0.80 & 5.00 & 3.00 & 5.00 & 5.00 & 5.00 & 4.60 \\
\hline 1780 & -0.65 & 5.00 & 3.00 & 5.00 & 5.00 & 5.00 & 4.60 \\
\hline 1790 & -0.60 & 5.00 & 3.00 & 5.00 & 5.00 & 5.00 & 4.60 \\
\hline 1800 & -0.50 & 5.00 & 3.00 & 5.00 & 5.00 & 5.00 & 4.60 \\
\hline 1810 & -0.45 & 5.00 & 3.00 & 5.00 & 5.00 & 5.00 & 4.60 \\
\hline 1820 & -0.50 & 5.00 & 3.00 & 5.00 & 5.00 & 5.00 & 4.60 \\
\hline 1830 & -0.75 & 5.00 & 3.00 & 5.00 & 5.00 & 5.00 & 4.60 \\
\hline 1840 & -1.00 & 2.00 & 3.00 & 2.00 & 4.00 & 5.00 & 3.20 \\
\hline 1850 & -1.30 & 2.00 & 3.00 & 2.00 & 4.00 & 5.00 & 3.20 \\
\hline 1860 & -1.40 & 2.00 & 3.00 & 2.00 & 4.00 & 5.00 & 3.20 \\
\hline 1870 & -1.35 & 2.00 & 3.00 & 2.00 & 4.00 & 5.00 & 3.20 \\
\hline 1880 & -1.25 & 2.00 & 3.00 & 2.00 & 4.00 & 5.00 & 3.20 \\
\hline 1890 & -0.75 & 2.00 & 3.00 & 2.00 & 4.00 & 5.00 & 3.20 \\
\hline 1900 & 0.00 & 2.00 & 3.00 & 2.00 & 4.00 & 5.00 & 3.20 \\
\hline 1910 & 0.05 & 2.00 & 3.00 & 2.00 & 4.00 & 5.00 & 3.20 \\
\hline 1920 & 0.00 & 1.00 & 2.00 & 1.00 & 2.00 & 2.00 & 1.60 \\
\hline 1930 & -0.10 & 1.00 & 2.00 & 1.00 & 2.00 & 2.00 & 1.60 \\
\hline 1940 & -0.20 & 1.00 & 2.00 & 1.00 & 2.00 & 2.00 & 1.60 \\
\hline 1950 & 0.00 & 1.00 & 2.00 & 1.00 & 2.00 & 2.00 & 1.60 \\
\hline 1960 & 0.25 & 1.00 & 1.00 & 1.00 & 1.00 & 1.00 & 1.00 \\
\hline 1970 & 0.40 & 1.00 & 1.00 & 1.00 & 1.00 & 1.00 & 1.00 \\
\hline 1980 & 0.55 & 1.00 & 3.00 & 1.00 & 1.00 & 1.00 & 1.40 \\
\hline 1990 & 0.70 & 1.00 & 3.00 & 1.00 & 1.00 & 1.00 & 1.40 \\
\hline 2000 & 0.85 & 1.00 & 3.00 & 1.00 & 1.00 & 1.00 & 1.40 \\
\hline
\end{tabular}

Table A7. Correlation analysis of temperature change and cultural system change.

\begin{tabular}{cccccc}
\hline Year & $\begin{array}{c}\text { Temperature } \\
\left(\mathbf{x} /{ }^{\circ} \mathbf{C}\right)\end{array}$ & $\begin{array}{c}\text { Construction Scale of } \\
\text { the Nanyuan Garden }\end{array}$ & $\begin{array}{c}\text { Innovation Level of } \\
\text { Cantonese Style } \\
\text { Furniture }\end{array}$ & $\begin{array}{c}\text { Innovation Level } \\
\text { of Musical } \\
\text { Instrument }\end{array}$ & $\begin{array}{c}\text { Cultural System } \\
\text { Mean }\left(\mathbf{y}_{3}\right)\end{array}$ \\
\hline 1000 & 0.40 & 2.00 & 3.00 & 2.00 & 2.33 \\
1010 & 0.35 & 2.00 & 3.00 & 2.00 & 2.33 \\
1020 & 0.25 & 2.00 & 3.00 & 2.00 & 2.33 \\
1030 & 0.20 & 2.00 & 3.00 & 2.00 & 2.33 \\
1040 & 0.10 & 2.00 & 3.00 & 2.00 & 2.33 \\
1050 & 0.08 & 2.00 & 3.00 & 2.00 & 2.33 \\
1060 & 0.05 & 2.00 & 3.00 & & \\
\hline
\end{tabular}


Table A7. Cont.

\begin{tabular}{|c|c|c|c|c|c|}
\hline Year & $\begin{array}{l}\text { Temperature } \\
\left(\mathrm{x} /{ }^{\circ} \mathrm{C}\right)\end{array}$ & $\begin{array}{l}\text { Construction Scale of } \\
\text { the Nanyuan Garden }\end{array}$ & $\begin{array}{c}\text { Innovation Level of } \\
\text { Cantonese Style } \\
\text { Furniture }\end{array}$ & $\begin{array}{c}\text { Innovation Level } \\
\text { of Musical } \\
\text { Instrument }\end{array}$ & $\begin{array}{c}\text { Cultural System } \\
\text { Mean }\left(\mathrm{y}_{3}\right)\end{array}$ \\
\hline 1070 & 0.02 & 2.00 & 3.00 & 2.00 & 2.33 \\
\hline 1080 & 0.00 & 2.00 & 3.00 & 2.00 & 2.33 \\
\hline 1090 & -0.05 & 2.00 & 3.00 & 2.00 & 2.33 \\
\hline 1100 & -0.15 & 2.00 & 3.00 & 2.00 & 2.33 \\
\hline 1110 & -1.45 & 2.00 & 3.00 & 2.00 & 2.33 \\
\hline 1120 & -1.60 & 2.00 & 3.00 & 2.00 & 2.33 \\
\hline 1130 & -1.75 & 2.00 & 3.00 & 2.00 & 2.33 \\
\hline 1140 & -1.80 & 2.00 & 3.00 & 2.00 & 2.33 \\
\hline 1150 & -1.85 & 2.00 & 3.00 & 2.00 & 2.33 \\
\hline 1160 & -1.80 & 2.00 & 3.00 & 2.00 & 2.33 \\
\hline 1170 & -1.75 & 2.00 & 3.00 & 2.00 & 2.33 \\
\hline 1180 & -1.70 & 2.00 & 3.00 & 2.00 & 2.33 \\
\hline 1190 & -1.50 & 2.00 & 3.00 & 2.00 & 2.33 \\
\hline 1200 & -0.40 & 2.00 & 3.00 & 2.00 & 2.33 \\
\hline 1210 & -0.30 & 2.00 & 3.00 & 2.00 & 2.33 \\
\hline 1220 & -0.25 & 2.00 & 3.00 & 2.00 & 2.33 \\
\hline 1230 & -0.30 & 2.00 & 3.00 & 2.00 & 2.33 \\
\hline 1240 & -0.75 & 2.00 & 3.00 & 2.00 & 2.33 \\
\hline 1250 & -1.25 & 2.00 & 3.00 & 2.00 & 2.33 \\
\hline 1260 & -1.75 & 2.00 & 3.00 & 2.00 & 2.33 \\
\hline 1270 & -1.85 & 2.00 & 3.00 & 3.00 & 2.67 \\
\hline 1280 & -1.80 & 2.00 & 3.00 & 3.00 & 2.67 \\
\hline 1290 & -1.50 & 2.00 & 3.00 & 3.00 & 2.67 \\
\hline 1300 & -1.00 & 2.00 & 3.00 & 3.00 & 2.67 \\
\hline 1310 & -1.10 & 2.00 & 3.00 & 3.00 & 2.67 \\
\hline 1320 & -1.80 & 2.00 & 3.00 & 3.00 & 2.67 \\
\hline 1330 & -1.75 & 2.00 & 3.00 & 3.00 & 2.67 \\
\hline 1340 & -1.60 & 2.00 & 3.00 & 3.00 & 2.67 \\
\hline 1350 & -1.50 & 2.00 & 3.00 & 3.00 & 2.67 \\
\hline 1360 & -1.25 & 4.00 & 3.00 & 3.00 & 3.33 \\
\hline 1370 & -1.15 & 4.00 & 3.00 & 3.00 & 3.33 \\
\hline 1380 & -1.00 & 4.00 & 3.00 & 3.00 & 3.33 \\
\hline 1390 & -0.80 & 2.00 & 5.00 & 5.00 & 4.00 \\
\hline 1400 & -0.90 & 2.00 & 5.00 & 5.00 & 4.00 \\
\hline 1410 & -1.00 & 2.00 & 5.00 & 5.00 & 4.00 \\
\hline 1420 & -1.10 & 2.00 & 5.00 & 5.00 & 4.00 \\
\hline 1430 & -1.20 & 2.00 & 5.00 & 5.00 & 4.00 \\
\hline 1440 & -1.25 & 2.00 & 5.00 & 5.00 & 4.00 \\
\hline 1450 & -1.30 & 2.00 & 5.00 & 5.00 & 4.00 \\
\hline 1460 & -1.35 & 2.00 & 5.00 & 5.00 & 4.00 \\
\hline 1470 & -1.40 & 2.00 & 5.00 & 5.00 & 4.00 \\
\hline 1480 & -1.45 & 2.00 & 5.00 & 5.00 & 4.00 \\
\hline 1490 & -1.50 & 2.00 & 5.00 & 5.00 & 4.00 \\
\hline 1500 & -1.45 & 2.00 & 5.00 & 5.00 & 4.00 \\
\hline 1510 & -1.40 & 2.00 & 5.00 & 5.00 & 4.00 \\
\hline 1520 & -1.30 & 2.00 & 5.00 & 5.00 & 4.00 \\
\hline 1530 & -1.25 & 2.00 & 5.00 & 5.00 & 4.00 \\
\hline 1540 & -1.20 & 3.00 & 5.00 & 5.00 & 4.33 \\
\hline 1550 & -1.15 & 3.00 & 5.00 & 5.00 & 4.33 \\
\hline 1560 & -1.10 & 3.00 & 5.00 & 5.00 & 4.33 \\
\hline 1570 & -1.15 & 3.00 & 5.00 & 5.00 & 4.33 \\
\hline 1580 & -1.20 & 3.00 & 5.00 & 5.00 & 4.33 \\
\hline 1590 & -1.25 & 3.00 & 5.00 & 5.00 & 4.33 \\
\hline 1600 & -1.35 & 3.00 & 3.00 & 3.00 & 3.00 \\
\hline 1610 & -1.50 & 3.00 & 3.00 & 3.00 & 3.00 \\
\hline
\end{tabular}


Table A7. Cont.

\begin{tabular}{|c|c|c|c|c|c|}
\hline Year & $\begin{array}{c}\text { Temperature } \\
\left(\mathrm{x} /{ }^{\circ} \mathrm{C}\right)\end{array}$ & $\begin{array}{l}\text { Construction Scale of } \\
\text { the Nanyuan Garden }\end{array}$ & $\begin{array}{c}\text { Innovation Level of } \\
\text { Cantonese Style } \\
\text { Furniture }\end{array}$ & $\begin{array}{c}\text { Innovation Level } \\
\text { of Musical } \\
\text { Instrument }\end{array}$ & $\begin{array}{c}\text { Cultural System } \\
\text { Mean }\left(\mathrm{y}_{3}\right)\end{array}$ \\
\hline 1620 & -1.60 & 3.00 & 3.00 & 3.00 & 3.00 \\
\hline 1630 & -1.70 & 3.00 & 3.00 & 3.00 & 3.00 \\
\hline 1640 & -1.75 & 3.00 & 3.00 & 3.00 & 3.00 \\
\hline 1650 & -1.85 & 1.00 & 5.00 & 5.00 & 3.67 \\
\hline 1660 & -1.75 & 1.00 & 5.00 & 5.00 & 3.67 \\
\hline 1670 & -1.70 & 1.00 & 5.00 & 5.00 & 3.67 \\
\hline 1680 & -1.65 & 1.00 & 5.00 & 5.00 & 3.67 \\
\hline 1690 & -1.60 & 2.00 & 5.00 & 5.00 & 4.00 \\
\hline 1700 & -1.55 & 2.00 & 5.00 & 5.00 & 4.00 \\
\hline 1710 & -1.50 & 2.00 & 5.00 & 5.00 & 4.00 \\
\hline 1720 & -1.40 & 2.00 & 5.00 & 5.00 & 4.00 \\
\hline 1730 & -1.30 & 2.00 & 5.00 & 5.00 & 4.00 \\
\hline 1740 & -1.20 & 2.00 & 5.00 & 5.00 & 4.00 \\
\hline 1750 & -1.10 & 2.00 & 5.00 & 5.00 & 4.00 \\
\hline 1760 & -0.95 & 2.00 & 5.00 & 5.00 & 4.00 \\
\hline 1770 & -0.80 & 2.00 & 5.00 & 5.00 & 4.00 \\
\hline 1780 & -0.65 & 2.00 & 5.00 & 5.00 & 4.00 \\
\hline 1790 & -0.60 & 2.00 & 5.00 & 5.00 & 4.00 \\
\hline 1800 & -0.50 & 2.00 & 5.00 & 5.00 & 4.00 \\
\hline 1810 & -0.45 & 2.00 & 5.00 & 5.00 & 4.00 \\
\hline 1820 & -0.50 & 2.00 & 5.00 & 5.00 & 4.00 \\
\hline 1830 & -0.75 & 2.00 & 5.00 & 5.00 & 4.00 \\
\hline 1840 & -1.00 & 3.00 & 4.00 & 5.00 & 4.00 \\
\hline 1850 & -1.30 & 3.00 & 4.00 & 5.00 & 4.00 \\
\hline 1860 & -1.40 & 3.00 & 4.00 & 5.00 & 4.00 \\
\hline 1870 & -1.35 & 3.00 & 4.00 & 5.00 & 4.00 \\
\hline 1880 & -1.25 & 3.00 & 4.00 & 5.00 & 4.00 \\
\hline 1890 & -0.75 & 4.00 & 4.00 & 5.00 & 4.33 \\
\hline 1900 & 0.00 & 4.00 & 4.00 & 5.00 & 4.33 \\
\hline 1910 & 0.05 & 5.00 & 4.00 & 4.00 & 4.33 \\
\hline 1920 & 0.00 & 2.00 & 2.00 & 2.00 & 2.00 \\
\hline 1930 & -0.10 & 2.00 & 2.00 & 2.00 & 2.00 \\
\hline 1940 & -0.20 & 2.00 & 2.00 & 2.00 & 2.00 \\
\hline 1950 & 0.00 & 2.00 & 2.00 & 2.00 & 2.00 \\
\hline 1960 & 0.25 & 1.00 & 1.00 & 1.00 & 1.00 \\
\hline 1970 & 0.40 & 1.00 & 1.00 & 1.00 & 1.00 \\
\hline 1980 & 0.55 & 1.00 & 1.00 & 1.00 & 1.00 \\
\hline 1990 & 0.70 & 1.00 & 1.00 & 1.00 & 1.00 \\
\hline 2000 & 0.85 & 1.00 & 1.00 & 1.00 & 1.00 \\
\hline
\end{tabular}

Table A8. $p$ value of long-term correlation analysis.

\begin{tabular}{ccccc}
\hline & Temperature Change & Natural System & Economic System & Cultural System \\
\hline Temperature Change & - & - & - & - \\
Natural System & $2.74 \times 10^{-82}$ & - & - & - \\
Economic System & 0.90348 & 0.00040 & - & - \\
Cultural System & $1.92 \times 10^{-87}$ & 0.86886 & 0.00009 & - \\
\hline
\end{tabular}


Table A9. $p$ value of short-term correlation analysis.

\begin{tabular}{|c|c|c|c|c|c|c|c|c|c|c|c|c|}
\hline \multirow{2}{*}{$\begin{array}{l}\text { Period of } \\
\text { Time }\end{array}$} & \multicolumn{4}{|c|}{$1250-1400$} & \multicolumn{4}{|c|}{$1550-1700$} & \multicolumn{4}{|c|}{ 1800-1950 } \\
\hline & $\begin{array}{l}\text { Temperature } \\
\text { Change }\end{array}$ & $\begin{array}{l}\text { Natural } \\
\text { System }\end{array}$ & $\begin{array}{l}\text { Economic } \\
\text { System }\end{array}$ & $\begin{array}{l}\text { Cultural } \\
\text { System }\end{array}$ & $\begin{array}{l}\text { Temperature } \\
\text { Change }\end{array}$ & $\begin{array}{l}\text { Natural } \\
\text { System }\end{array}$ & $\begin{array}{l}\text { Economic } \\
\text { System }\end{array}$ & $\begin{array}{l}\text { Cultural } \\
\text { System }\end{array}$ & $\begin{array}{l}\text { Temperature } \\
\text { Change }\end{array}$ & $\begin{array}{l}\text { Natural } \\
\text { System }\end{array}$ & $\begin{array}{l}\text { Economic } \\
\text { System }\end{array}$ & $\begin{array}{l}\text { Cultural } \\
\text { System }\end{array}$ \\
\hline $\begin{array}{c}\text { Temperature } \\
\text { Change }\end{array}$ & - & - & - & - & - & - & - & - & - & - & - & - \\
\hline $\begin{array}{l}\text { Natural } \\
\text { System }\end{array}$ & $\begin{array}{l}1.15 \times \\
10^{-25}\end{array}$ & - & - & - & $\begin{array}{l}1.52 \times \\
10^{-30}\end{array}$ & - & - & - & $\begin{array}{l}1.94 \times \\
10^{-14}\end{array}$ & - & - & - \\
\hline $\begin{array}{l}\text { Economic } \\
\text { System }\end{array}$ & $\begin{array}{l}4.60 \times \\
10^{-24}\end{array}$ & $\begin{array}{c}8.52 \times \\
10^{-5}\end{array}$ & - & - & $\begin{array}{l}2.28 \times \\
10^{-26}\end{array}$ & $\begin{array}{l}1.58 \times \\
10^{-12}\end{array}$ & - & - & $\begin{array}{l}3.14 \times \\
10^{-13}\end{array}$ & 0.0021 & - & - \\
\hline $\begin{array}{l}\text { Cultural } \\
\text { System }\end{array}$ & $\begin{array}{l}1.30 \times \\
10^{-22}\end{array}$ & $\begin{array}{c}7.67 \times \\
10^{-7}\end{array}$ & 0.0367 & - & $\begin{array}{l}1.53 \times \\
10^{-25}\end{array}$ & $\begin{array}{c}1.19 \times \\
10^{-8}\end{array}$ & 0.0027 & - & $\begin{array}{c}9.10 \times \\
10^{-16}\end{array}$ & $\begin{array}{l}1.06 \times \\
10^{-5}\end{array}$ & 0.0263 & - \\
\hline
\end{tabular}

\section{References}

1. Bloom, D.E.; Canning, D.; Fink, G. Urbanization and the wealth of nations. Science 2008, 319, 772-775. [CrossRef] [PubMed]

2. Di Giulio, M.; Holderegger, R.; Tobias, S. Effects of habitat and landscape fragmentation on humans and biodiversity in densely populated landscapes. J. Environ. Manag. 2009, 90, 2959-2968. [CrossRef] [PubMed]

3. Fakhouri, L.A.; Haddad, N.A. Aspects of the architectural and urban heritage: From registers to conservation for adaptive and modern use at the historic cores of salt and irbid, jordan. Archnet-IJAR 2017, 11, 190-218. [CrossRef]

4. Hou, H.; Estoque, R.C. Detecting Cooling Effect of Landscape from Composition and Configuration: An Urban Heat Island Study on Hangzhou. Urban For. Urban Green. 2020, 53, 12. [CrossRef]

5. Jorgenson, A.K.; Burns, T.J. Effects of rural and urban population dynamics and national development on deforestation in less-developed countries, 1990-2000. Sociol. Inq. 2007, 77, 460-482. [CrossRef]

6. Syrbe, R.U.; Neumann, I.; Grunewald, K.; Brzoska, P.; Louda, J.; Kochan, B.; Machac, J.; Dubova, L.; Meyer, P.; Brabec, J.; et al. The Value of Urban Nature in Terms of Providing Ecosystem Services Related to Health and Well-Being: An Empirical Comparative Pilot Study of Cities in Germany and the Czech Republic. Land 2021, 10, 341. [CrossRef]

7. Wu, Z.J.; Zhang, Y.X. Water Bodies' Cooling Effects on Urban Land Daytime Surface Temperature: Ecosystem Service Reducing Heat Island Effect. Sustainability 2019, 11, 787. [CrossRef]

8. Muller, J. Transforming Our World: The 2030 Agenda for Sustainable Development 25 September 2015. In Reforming the United Nations: A Chronology; Muller, J., Ed.; Brill: Leiden, The Netherlands, 2016; Volume 7, pp. 223-263.

9. Alberti, M. Simulation and Design of Hybrid Human-NaturalTechnological Systems. Technol. Archit. Des. 2017, 1, 135-139. [CrossRef]

10. Liao, K.H. A Theory on Urban Resilience to Floods-A Basis for Alternative Planning Practices. Ecol. Soc. 2012, 17, 15. [CrossRef]

11. Meerow, S.; Newell, J.P.; Stults, M. Defining urban resilience: A review. Landsc. Urban Plan. 2016, 147, 38-49. [CrossRef]

12. Cerra, J.F. Inland Adaptation: Developing a Studio Model for Climate-adaptive Design as a Framework for Design Practice. Landsc. J. 2016, 35, 37-55. [CrossRef]

13. Huang, L.; Xiang, W.N.; Wu, J.G.; Traxler, C.; Huang, J.Z. Integrating GeoDesign with Landscape Sustainability Science. Sustainability 2019, 11, 833. [CrossRef]

14. Arnold, C.L.; Gibbons, C.J. Impervious surface coverage-The emergence of a key environmental indicator. J. Am. Plan. Assoc. 1996, 62, 243-258. [CrossRef]

15. Kwak, Y.; Deal, B.; Mosey, G. Landscape Design toward Urban Resilience: Bridging Science and Physical Design Coupling Sociohydrological Modeling and Design Process. Sustainability 2021, 13, 4666. [CrossRef]

16. Opdam, P.; Luque, S.; Nassauer, J.; Verburg, P.H.; Wu, J. How can landscape ecology contribute to sustainability science? Landsc. Ecol. 2018, 33, 1-7. [CrossRef]

17. UNESCO (United Nations Educational, Scientific and Cultural Organization). Recommendation on the historic urban landscape. In Proceedings of the Records of the General Conference 36th Session, Paris, France, 15 October-10 Novermber 2011.

18. Cao, S.Y.; Liu, X.N.; Er, H.A. Dujiangyan Irrigation System-A world cultural heritage corresponding to concepts of modern hydraulic science. J. Hydro-Environ. Res. 2010, 4, 3-13. [CrossRef]

19. DeCandido, R.; Calvanese, N.; Alvarez, R.V.; Brown, M.I.; Nelson, T.M. The naturally occurring historical and extant flora of Central Park, New York City, New York 1857-2007. J. Torrey Bot. Soc. 2007, 134, 552-569. [CrossRef]

20. Li, K.; Xu, Z.F. Overview of Dujiangyan Irrigation Scheme of ancient China with current theory. Irrig. Drain. 2006, 55, 291-298. [CrossRef]

21. Zhang, L.X.; Yang, Z.F.; Voinov, A.; Gao, S. Nature-inspired stormwater management practice: The ecological wisdom underlying the Tuanchen drainage system in Beijing, China and its contemporary relevance. Landsc. Urban Plan. 2016, 155, 11-20. [CrossRef]

22. Ginzarly, M.; Houbart, C.; Teller, J. The Historic Urban Landscape approach to urban management: A systematic review. Int. J. Herit. Stud. 2019, 25, 999-1019. [CrossRef]

23. Shamsuddin, S.; Sulaiman, A.B.; Amat, R.C. Urban Landscape Factors That Influenced the Character of George Town, Penang Unesco World Heritage Site. In Proceedings of the ASEAN Conference on Environment-Behaviour Studies (AcE-Bs) on Way of Life-Socio-Economic and Cultural Context, King Mongkuts Inst Technol Ladkrabang (KMITL), Fac Architecture, Bangkok, Thailand, 16-18 July 2012; pp. 238-253. 
24. Gravagnuolo, A.; Girard, L.F. Multicriteria Tools for the Implementation of Historic Urban Landscape. Qual. Innov. Prosper. 2017, 21, 186-201. [CrossRef]

25. Girard, L.F. Toward a Smart Sustainable Development of Port Cities/Areas: The Role of the "Historic Urban Landscape" Approach. Sustainability 2013, 5, 4329-4348. [CrossRef]

26. Veldpaus, L.; Roders, A.R.P.; Colenbrander, B.J.F. Urban Heritage: Putting the Past into the Future. Hist. Environ. Policy Pract. 2013, 4, 3-18. [CrossRef]

27. Chahardowli, M.; Sajadzadeh, H.; Aram, F.; Mosavi, A. Survey of Sustainable Regeneration of Historic and Cultural Cores of Cities. Energies 2020, 13, 2708. [CrossRef]

28. Rodwell, D. Reconnecting the city: The historic landscape approach and the future of urban heritage. J. Archit. Conserv. 2015, 21, 136-138. [CrossRef]

29. Zhang, L.; Cong, C.; Pan, H.Z.; Cai, Z.P.; Cvetkovic, V.; Deal, B. Socioecological informed comparative modeling to promote sustainable urban policy transitions: Case study in Chicago and Stockholm. J. Clean Prod. 2021, 281, 12. [CrossRef]

30. Mortberg, U.; Haas, J.; Zetterberg, A.; Franklin, J.P.; Jonsson, D.; Deal, B. Urban ecosystems and sustainable urban developmentanalysing and assessing interacting systems in the Stockholm region. Urban Ecosyst. 2013, 16, 763-782. [CrossRef]

31. Tillman, J. Design for Human Ecosystems; Island Press: Washinton, DC, USA, 1999.

32. Zeng, Z.X. Guangzhou Historical Geography, 1st ed.; Zhang, J.X., Ed.; Guangdong People's Publishing House: Guangzhou, China, 1991; pp. 153-195. (In Chinese)

33. Qu, D.J. Guangdong Xinyu; China Publishing House: Shanghai, China, 1985; pp. 460-476. (In Chinese)

34. Oudin, L.; Salavati, B.; Furusho-Percot, C.; Ribstein, P.; Saadi, M. Hydrological impacts of urbanization at the catchment scale. J. Hydrol. 2018, 559, 774-786. [CrossRef]

35. Wu, J.Y.; Thompson, J.R.; Kolka, R.K.; Franz, K.J.; Stewart, T.W. Using the Storm Water Management Model to predict urban headwater stream hydrological response to climate and land cover change. Hydrol. Earth Syst. Sci. 2013, 17, 4743-4758. [CrossRef]

36. Zope, P.E.; Eldho, T.I.; Jothiprakash, V. Hydrological impacts of land use-land cover change and detention basins on urban flood hazard: A case study of Poisar River basin, Mumbai, India. Nat. Hazards 2017, 87, 1267-1283. [CrossRef]

37. Guzman, P.; Roders, A.R.P.; Colenbrander, B. Impacts of Common Urban Development Factors on Cultural Conservation in World Heritage Cities: An Indicators-Based Analysis. Sustainability 2018, 10, 853. [CrossRef]

38. Zhao, Y.; Xiao, L. Analysis on the landsense creation of Chinese classical poetry and mountains-and-waters painting based on landsenses ecology. Int. J. Sustain. Dev. World Ecol. 2020, 27, 292-296. [CrossRef]

39. Joohyun, L. Western Artists visiting Trading Ports in China: Focusing on Macau, Canton and Hongkong. J. Korean Mod. Contemp. Art Hist. 2014, 28, 113-143.

40. Cai, Y.A. Cantonese-Style Furniture in Qing Dynasty, 1st ed.; Shanghai Bookstore Publishing House: Shanghai, China, 2001 ; p. 53. (In Chinese)

41. Osgood, C.E. The Measurement of Meaning; University Of Illinois Press: Champaign, IL, USA, 1967.

42. Bradley, M.M.; Lang, P.J. Measuring emotion: The Self-Assessment Manikin and the semantic differential. J. Behav. Ther. Exp. Psychiatry 1994, 25, 49-59. [CrossRef]

43. Ahmad, S.N.; Laroche, M. How Do Expressed Emotions Affect the Helpfulness of a Product Review? Evidence from Reviews Using Latent Semantic Analysis. Int. J. Electron. Commer. 2016, 20, 76-111. [CrossRef]

44. Li, C.L.; Li, X.G.; Zhao, W. On the Optimization of Rural Settlement Space Planning Method Based on Semantic Analysis of Ancient Poetry-A Case Study of the Chengdu Plain. Chin. Landsc. Archit. 2020, 36, 76-81. (In Chinese) [CrossRef]

45. Song, C.R.; Ikei, H.; Igarashi, M.; Takagaki, M.; Miyazaki, Y. Physiological and Psychological Effects of a Walk in Urban Parks in Fall. Int. J. Environ. Res. Public Health 2015, 12, 14216-14228. [CrossRef] [PubMed]

46. Natori, Y.; Chenoweth, R. Differences in rural landscape perceptions and preferences between farmers and naturalists. J. Environ. Psychol. 2008, 28, 250-267. [CrossRef]

47. Beza, B.B. The aesthetic value of a mountain landscape: A study of the Mt. Everest Trek. Landsc. Urban Plan. 2010, 97, 306-317. [CrossRef]

48. Jeon, J.Y.; Jo, H.I. Effects of audio-visual interactions on soundscape and landscape perception and their influence on satisfaction with the urban environment. Build. Environ. 2020, 169, 12. [CrossRef]

49. Baron, J.S.; Poff, N.L.; Angermeier, P.L.; Dahm, C.N.; Gleick, P.H.; Hairston, N.G.; Jackson, R.B.; Johnston, C.A.; Richter, B.D.; Steinman, A.D. Meeting ecological and societal needs for freshwater. Ecol. Appl. 2002, 12, 1247-1260. [CrossRef]

50. Kingsford, R.T.; Basset, A.; Jackson, L. Wetlands: Conservation's poor cousins. Aquat. Conserv. Mar. Freshw. Ecosyst. 2016, 26, 892-916. [CrossRef]

51. Zhou, H.J.; Shi, P.J.; Wang, J.A.; Yu, D.Y.; Gao, L. Rapid Urbanization and Implications for River Ecological Services Restoration: Case Study in Shenzhen, China. J. Urban Plan. Dev. ASCE 2011, 137, 121-132. [CrossRef]

52. Fang, X.R.; Fan, F. Hundred Odes of South China Sea; Tai Tung Book Company: Hongkong, China, 1977. (In Chinese)

53. Qiu, J.C. Antiquities of Canton, 1st ed.; Guangdong People's Publishing House: Guangzhou, China, 1993 ; Volume 1, p. 97. (In Chinese)

54. Guzman, P. Assessing the sustainable development of the historic urban landscape through local indicators. Lessons from a Mexican World Heritage City. J. Cult. Herit. 2020, 46, 320-327. [CrossRef] 
55. Zhu, K.Z. A preliminary study on climate change in China during the last five thousand years. Sci. China 1973, 2, 168-169. (In Chinese)

56. Ge, Q.S.; Zheng, J.Y.; Fang, X.Q.; Man, Z.M.; Zhang, X.Q.; Zhang, P.Y.; Wang, W.C. Winter half-year temperature reconstruction for the middle and lower reaches of the Yellow River and Yangtze River, China, during the past 2000 years. Holocene 2003, 13, 933-940. [CrossRef]

57. Ge, Q.S.; Zheng, J.Y.; Hao, Z.X.; Liu, Y.; Li, M.Q. Recent advances on reconstruction of climate and extreme events in China for the past 2000 years. J. Geogr. Sci. 2016, 26, 827-854. [CrossRef]

58. Wei, Z.D.; Fang, X.Q.; Su, Y. Climate change and fiscal balance in China over the past two millennia. Holocene 2014, 24, 1771-1784. [CrossRef]

59. Wei, Z.; Fang, X.; Su, Y. A preliminary analysis of economic fluctuations and climate changes in China from BC 220 to AD 1910. Reg. Environ. Chang. 2015, 15, 1773-1785. [CrossRef]

60. Wei, Z.D.; Rosen, A.M.; Fang, X.Q.; Su, Y.; Zhang, X.Z. Macro-economic cycles related to climate change in dynastic China. Quat. Res. 2015, 83, 13-23. [CrossRef]

61. Ruan, Y. Guangdong Annals; Shanghai Classics Publishing House: Shanghai, China, 1990; Volume 7. (In Chinese)

62. Huang, F.Y. Records of Guangzhou City, 1st ed.; Guangdong People's Publishing House: Guangzhou, China, 1994. (In Chinese)

63. Barrientos, F.; Martin, J.; De Luca, C.; Tondelli, S.; Gomez-Garcia-Bermejo, J.; Casanova, E.Z. Computational methods and rural cultural \& natural heritage: A review. J. Cult. Herit. 2021, 49, 250-259. [CrossRef]

64. Pham, V.; Nghiem, S.V.; Pham, C.V.; Luu, M.P.T.; Bui, Q.T. Urbanization impact on landscape patterns in cultural heritage preservation sites: A case study of the complex of Hue Monuments, Vietnam. Landsc. Ecol. 2021, 36, 1235-1260. [CrossRef]

65. Fagan, B. The Little Ice Age: How Climate Made History 1300-1850; Basic Books: New York, NY, USA, 2001.

66. Zhang, D.D.; Brecke, P.; Lee, H.F.; He, Y.Q.; Zhang, J. Global climate change, war, and population decline in recent human history. Proc. Natl. Acad. Sci. USA 2007, 104, 19214-19219. [CrossRef]

67. Styers, D.M.; Chappelka, A.H.; Marzen, L.J.; Somers, G.L. Developing a land-cover classification to select indicators of forest ecosystem health in a rapidly urbanizing landscape. Landsc. Urban Plan. 2010, 94, 158-165. [CrossRef]

68. Weng, Q.H.; Yang, S.H. Managing the adverse thermal effects of urban development in a densely populated Chinese city. J. Environ. Manag. 2004, 70, 145-156. [CrossRef] [PubMed] 